\title{
Hydrogen Evolution from Water under Visible-Light Irradiation Using Keggin-Type Platinum(II)-Coordinated Phospho-, Silico-, and Germanotungstates as Co-Catalysts
}

\author{
Chika Nozaki Kato1,2*, Shunsaku Suzuki', Yuki Ihara1, Koki Aono¹, Rie Yamashita ${ }^{3}$, Keisuke Kikuchi' \\ Tetsuji Okamoto ${ }^{3}$, Hidemitsu Uno ${ }^{4}$ \\ ${ }^{1}$ Department of Chemistry, Shizuoka University, Shizuoka, Japan \\ ${ }^{2}$ Green Chemistry Research Division, Research Institute of Green Science and Technology, Shizuoka University, Shizuoka, Japan \\ ${ }^{3}$ Industrial Research Institute of Shizuoka Prefecture, Shizuoka, Japan \\ ${ }^{4}$ Department of Chemistry and Biology, Graduate School of Science and Engineering, Ehime University, Matsuyama, Japan \\ Email: ${ }^{*}$ kato.chika@shizuoka.ac.jp
}

How to cite this paper: Kato, C.N., Suzuki, S., Ihara, Y., Aono, K., Yamashita, R., Kikuchi, K., Okamoto, T. and Uno, H. (2016) Hydrogen Evolution from Water under Visible-Light Irradiation Using Keggin-Type Platinum(II)-Coordinated Phospho-, Silico-, and Germanotungstates as Co-Catalysts. $\mathrm{Mo}$ dern Research in Catalysis, 5, 103-129.

http://dx.doi.org/10.4236/mrc.2016.54010

Received: April 22, 2016

Accepted: September 24, 2016

Published: September 27, 2016

Copyright $\odot 2016$ by authors and Scientific Research Publishing Inc. This work is licensed under the Creative Commons Attribution International License (CC BY 4.0).

http://creativecommons.org/licenses/by/4.0/

\begin{abstract}
The tetramethylammonium salts of diplatinum(II) complexes composed of monolacunary Keggin-type silico and germanotungstates, $\left[\left(\mathrm{CH}_{3}\right)_{4} \mathrm{~N}\right]_{4}\left[\alpha-\mathrm{SiW}_{11} \mathrm{O}_{39}\left\{c i s-\mathrm{Pt}\left(\mathrm{NH}_{3}\right)_{2}\right\}_{2}\right] \cdot 13 \mathrm{H}_{2} \mathrm{O}$ (TMA-Si-Pt) and $\left[\left(\mathrm{CH}_{3}\right)_{4} \mathrm{~N}\right]_{4}\left[\alpha-\mathrm{GeW}_{11} \mathrm{O}_{39}\left\{\text { cis-Pt }\left(\mathrm{NH}_{3}\right)_{2}\right\}_{2}\right] \cdot 11 \mathrm{H}_{2} \mathrm{O}$ (TMA-Ge-Pt), were synthesized and crystallized. Single crystals of a tetramethylammonium salt of Keggin-type diplatinum(II)-coordinated phosphotungstate $\left[\left(\mathrm{CH}_{3}\right)_{4} \mathrm{~N}\right]_{3}\left[\alpha-\mathrm{PW}_{11} \mathrm{O}_{39}\left\{\text { cis- } \mathrm{Pt}\left(\mathrm{NH}_{3}\right)_{2}\right\}_{2}\right] \cdot 10 \mathrm{H}_{2} \mathrm{O}$ (TMA-P-Pt) were also obtained. The $\mathrm{X}$-ray structural analyses revealed that the two cis-platinum(II) moieties, $\left[\text { cis- } \mathrm{Pt}\left(\mathrm{NH}_{3}\right)_{2}\right]^{2+}$, were each coordinated to two oxygen atoms in a mono-vacant site of $\left[\mathrm{XW}_{11} \mathrm{O}_{39}\right]^{(12-\mathrm{n})-}\left(\mathrm{X}^{\mathrm{n}+}=\mathrm{Si}^{4+}, \mathrm{Ge}^{4+}, \mathrm{P}^{5+}\right)$. FTIR spectra of TMA-Si-Pt and TMA-Ge-Pt also suggested that the two platinum(II) moieties were coordinated to the vacant site of $\left[\mathrm{SiW}_{11} \mathrm{O}_{39}\right]^{8-}$ and $\left[\mathrm{GeW}_{11} \mathrm{O}_{39}\right]^{8-}$. The ${ }^{1} \mathrm{H}$ NMR spectra in DMSO- $d_{6}$ of TMA-Si-Pt and TMA-Ge-Pt showed signals assigned to the two sets of $\mathrm{NH}_{3}$ ligands coordinated to the platinum sites. These three platinum compounds showed hydrogen evolution from aqueous triethanolamine solution under visible light irradiation $(\lambda \geq 400 \mathrm{~nm})$ in the presence of eosin Y, $\alpha$-Keggin mono-aluminum-substituted silicotungstate, and titanium dioxide. The catalytic activities were influenced by the central atoms, and TMA-P-Pt showed the highest activities among the three platinum compounds.
\end{abstract}

\section{Keywords}

Polyoxometalates, Diplatinum(II) Complex, Hydrogen Evolution, Visible Light, 
X-Ray Crystallography

\section{Introduction}

The development of photocatalysts, especially those that work under visible light irradiation, for the production of hydrogen from water is a critical issue in establishing clean energy systems [1]-[3]. Among the various possible photocatalysts, platinum is widely used as a co-catalyst to construct efficient photocatalytic systems for producing hydrogen because platinum promotes the separation of photo-generated electrons and holes and improves the efficiency of photocatalysis when it acts as the active center for hydrogen evolution [4].

Therefore, we have synthesized tetramethylammonium and cesium salts of $\alpha$-Keggin diplatinum-coordinated phosphotungstate, $\left[\left(\mathrm{CH}_{3}\right)_{4} \mathrm{~N}\right]_{3}\left[\mathrm{PW}_{11} \mathrm{O}_{39}\left\{\text { cis- } \mathrm{Pt}\left(\mathrm{NH}_{3}\right)_{2}\right\}_{2}\right] \cdot 10 \mathrm{H}_{2} \mathrm{O}$ (TMA-P-Pt) [5] and $\mathrm{Cs}_{3}\left[\alpha-\mathrm{PW}_{11} \mathrm{O}_{39}\left\{c i s-\mathrm{Pt}\left(\mathrm{NH}_{3}\right)_{2}\right\}_{2}\right] \cdot 8 \mathrm{H}_{2} \mathrm{O}$ (Cs-P-Pt) [6], and have constructed a novel photocatalytic system with Cs-P-Pt, eosin Y (EY), $\alpha$-Keggin mono-aluminum-substituted polyoxotungstate $\mathrm{K}_{5}\left[\alpha-\mathrm{SiW}_{11}\left\{\mathrm{Al}\left(\mathrm{OH}_{2}\right)\right\} \mathrm{O}_{39}\right] \cdot 7 \mathrm{H}_{2} \mathrm{O}(\mathrm{K}-\mathrm{Si}-\mathrm{Al})$, and titanium dioxide to improve the effective utilization of platinum sites. This system achieved a steady hydrogen production during $12 \mathrm{~h}$ of light irradiation with highly effective utilization of the platinum sites for hydrogen production from aqueous triethanolamine (TEA) solutions under visible light irradiation $(\lambda \geq 400 \mathrm{~nm}, \geq 440 \mathrm{~nm}$, and $\geq 500 \mathrm{~nm}$ ) [7]. During the light irradiation, we observed the formation of a reduced species (heteropoly blue species; HPB) of Cs-P-Pt, which was the key to achieving a steady hydrogen evolution during a $12 \mathrm{~h}$ of light irradiation. This is because it acted as a photosensitizer in the later stages, and compensated for the decline in hydrogen production caused by the decomposition of $\mathrm{EY}$. Fu and $\mathrm{Lu}[8]$ reported that the rate of HPB formation for $\mathrm{XW}_{12} \mathrm{O}_{40}{ }^{(8-\mathrm{n})-}\left(\mathrm{X}^{\mathrm{n}+}=\mathrm{P}^{5+}, \mathrm{Ge}^{4+}, \mathrm{Si}^{4+}, \mathrm{B}^{3+}\right)$ is a key factor in determining hydrogen evolution rates under visible light irradiation, which is influenced by the central atoms in the polyoxoanions. In contrast, Wang and co-workers [9] observed no significant effect of the central atom on hydrogen evolution from $20 \%$ methanol aqueous solution catalyzed by (HTEA) $)_{2}\left\{\left[\mathrm{Na}(\mathrm{TEA})_{2}\right] \mathrm{H}\left[\mathrm{SiW}_{12} \mathrm{O}_{40}\right]\right\} \cdot 5 \mathrm{H}_{2} \mathrm{O}$, $(\mathrm{HTEA})_{2}\left\{\left[\mathrm{Na}(\mathrm{TEA})_{2}\right]\left[\mathrm{PW}_{12} \mathrm{O}_{40}\right]\right\} \cdot 4 \mathrm{H}_{2} \mathrm{O}$, and (HTEA) $)_{2}\left\{\left[\mathrm{Na}(\mathrm{TEA})_{2}\right] \mathrm{H}\left[\mathrm{GeW}_{12} \mathrm{O}_{40}\right]\right\} \cdot 4 \mathrm{H}_{2} \mathrm{O}$ with $1 \% \mathrm{Pt}$ co-catalyst under a $300 \mathrm{~W}$ Xe lamp (without filter).

In this study, we synthesized the tetramethylammonium salts of Keggin-type diplatinum(II)-coordinated silico- and germanotungstates,

$\left[\left(\mathrm{CH}_{3}\right)_{4} \mathrm{~N}\right]_{4}\left[\alpha-\mathrm{SiW}_{11} \mathrm{O}_{39}\left\{c i s-\mathrm{Pt}\left(\mathrm{NH}_{3}\right)_{2}\right\}_{2}\right] \cdot 13 \mathrm{H}_{2} \mathrm{O}$ (TMA-Si-Pt) and $\left[\left(\mathrm{CH}_{3}\right)_{4} \mathrm{~N}\right]_{4}\left[\alpha-\mathrm{GeW}_{11} \mathrm{O}_{39}\left\{\text { cis- } \mathrm{Pt}\left(\mathrm{NH}_{3}\right)_{2}\right\}_{2}\right] \cdot 11 \mathrm{H}_{2} \mathrm{O}$ (TMA-Ge-Pt), by the reaction of monolacunary Keggin-type silico- or germanotungstate with cis-diamminedichloroplatinum(II) (cisplatin) in an aqueous solution. These compounds were characterized by $\mathrm{X}$-ray crystallography, elemental analysis, thermogravimetric/differential thermal analyses (TG/DTA), Fourier transform infrared (FTIR), cyclic voltammetry, and solution ${ }^{1} \mathrm{H}$ nuclear magnetic resonance (NMR) spectroscopy. The molecular structure of 
TMA-P-Pt was also determined by X-ray crystallography. Furthermore, we used TMA$\mathrm{P}-\mathrm{Pt}$, TMA-Si-Pt, and TMA-Ge-Pt as co-catalysts, and investigated their photocatalytic activities for hydrogen evolution from aqueous TEA solutions under light irradiation $(\lambda$ $\geq 400 \mathrm{~nm}$ ) in the presence of EY, K-Si-Al, and titanium dioxide. The rates of EY (and fluorescein-like species) decomposition and the amounts of HPB anions were also monitored by UV-Vis spectroscopy.

\section{Experimental}

\subsection{Materials and Methods}

The $\mathrm{K}_{8}\left[\mathrm{SiW}_{11} \mathrm{O}_{39}\right] \cdot 17 \mathrm{H}_{2} \mathrm{O}[10], \mathrm{K}_{6} \mathrm{Na}_{2}\left[\mathrm{GeW}_{11} \mathrm{O}_{39}\right] \cdot 12 \mathrm{H}_{2} \mathrm{O}[11]$, $\left[\left(\mathrm{CH}_{3}\right)_{4} \mathrm{~N}\right]_{3}\left[\alpha-\mathrm{PW}_{11} \mathrm{O}_{39}\left\{\text { cis-Pt }\left(\mathrm{NH}_{3}\right)_{2}\right\}_{2}\right] \cdot 10 \mathrm{H}_{2} \mathrm{O}$ (TMA-P-Pt) [5], and $\mathrm{K}_{5}\left[\alpha-\mathrm{SiW}_{11}\left\{\mathrm{Al}\left(\mathrm{OH}_{2}\right)\right\} \mathrm{O}_{39}\right] \cdot 7 \mathrm{H}_{2} \mathrm{O}(\mathrm{K}-\mathrm{Si}-\mathrm{Al})$ [7] were prepared as described in the literature. The number of solvated water molecules was determined by thermogravimetric/differential thermal analysis (TG/DTA).

$\left[\left(\mathrm{CH}_{3}\right)_{4} \mathrm{~N}\right]_{4}\left[\alpha-\mathrm{SiW}_{11} \mathrm{O}_{39}\left\{c i s-\mathrm{Pt}\left(\mathrm{NH}_{3}\right)_{2}\right\}_{2}\right] \cdot 13 \mathrm{H}_{2} \mathrm{O}$ (TMA-Si-Pt) and $\left[\left(\mathrm{CH}_{3}\right)_{4} \mathrm{~N}\right]_{4}\left[\alpha-\mathrm{GeW}_{11} \mathrm{O}_{39}\left\{c i s-\mathrm{Pt}\left(\mathrm{NH}_{3}\right)_{2}\right\}_{2}\right] \cdot 11 \mathrm{H}_{2} \mathrm{O}$ (TMA-Ge-Pt) were synthesized using a modification of the published method for TMA-P-Pt [5]. The synthesis and characterization of TMA-Si-Pt and TMA-Ge-Pt are described in the supporting information. The crystallization of TMA-P-Pt, TMA-Si-Pt, and TMA-Ge-Pt for X-ray crystallography is also described in the supporting information. All of the reagents and solvents were obtained from commercial sources and were used as received. Titanium dioxide (anatase:rutile $=80: 20$ ) was obtained from Wako Pure Chemical Industries, Ltd. The elemental analysis results for $\mathrm{C}, \mathrm{H}$, and $\mathrm{N}$ were obtained using Flash EA (Thermo Electron Corporation) at Shizuoka University (Japan). The elemental analysis of Si, Ge, Pt, and W was carried out by Mikroanalytisches Labor Pascher (Remagen, Germany) and the Industrial Research Institute of Shizuoka Prefecture (Japan). The samples were dried overnight at ambient temperatures under $10^{-3}-10^{-4}$ Torr vacuum before analysis. The TG/DTA data were obtained using Rigaku Thermo Plus EVO2 TG/DTA $81205 \mathrm{Z}$ instruments in air while increasing the temperature from $20^{\circ} \mathrm{C}$ to $500^{\circ} \mathrm{C}$ at a rate of $4^{\circ} \mathrm{C} / \mathrm{min}$. The ${ }^{1} \mathrm{H}(600.17 \mathrm{MHz})$ and ${ }^{31} \mathrm{P}-\left\{{ }^{1} \mathrm{H}\right\}(242.95 \mathrm{MHz}) \mathrm{NMR}$ spectra in solutions were recorded in 5-mm outer diameter tubes on a JEOL ECA-600 NMR spectrometer (Shizuoka University). The ${ }^{1} \mathrm{H}$ NMR spectra were measured in DMSO- $d_{6}$ with reference to an internal 3-(trimethylsilyl)-1-propanesulfonic acid sodium salt (DSS). Chemical shifts were reported as positive for resonances downfield of DSS $(\delta 0)$. The ${ }^{31} \mathrm{P}$ NMR spectra were measured in $\mathrm{D}_{2} \mathrm{O}$ with reference to an external standard of $85 \% \mathrm{H}_{3} \mathrm{PO}_{4}$ in a sealed capillary. Chemical shifts were reported as negative on the $\delta$ scale for resonances upfield of $\mathrm{H}_{3} \mathrm{PO}_{4}(\delta 0)$. Solution ultraviolet-visible (UV-Vis) spectra were recorded using a Perkin-Elmer Spectrum Lambda 650 spectrophotometer. Cyclic voltammetry was measured by the Industrial Research Institute of Shizuoka Prefecture, Japan. The measurements were carried out by using a glassy carbon working electrode (diameter, $3 \mathrm{~mm}$ ), a platinum wire counter electrode, and a $\mathrm{Ag} / \mathrm{AgCl}$ reference electrode (saturated $\mathrm{KCl}$, TOYO Corporation) at approximately 
$20^{\circ} \mathrm{C}$.

\subsection{X-Ray Crystallography}

A yellow block crystal of TMA-P-Pt $(0.080 \times 0.040 \times 0.040 \mathrm{~mm})$, TMA-Si-Pt (space group $\left.P 2_{1} / n\right)(0.060 \times 0.060 \times 0.050 \mathrm{~mm})$, TMA-Si-Pt (space group $\left.P 2_{1} / c\right)(0.080 \times$ $0.040 \times 0.040 \mathrm{~mm})$, TMA-Ge-Pt (space group $\left.P 2_{1} / n\right)(0.030 \times 0.030 \times 0.020 \mathrm{~mm})$, and TMA-Ge-Pt (space group $\left.P 2_{1} / c\right)(0.050 \times 0.030 \times 0.020 \mathrm{~mm})$ was mounted on a loop or MicroMount. The measurement for TMA-Ge-Pt (space group $P 2_{1} / n$ ) were obtained using a Rigaku VariMax with a Saturn diffractometer using multi-layer mirrormonochromated Mo K $\alpha$ radiation $(\lambda=0.71075 \AA)$ at $100 \pm 1 \mathrm{~K}$. The measurement for TMA-P-Pt, TMA-Si-Pt (space group $P 2_{1} / c$ ), TMA-Si-Pt (space group $P 2_{1} / c$ ), and TMA-Ge-Pt (space group $P 2_{1} / c$ ) was carried out using a Rigaku VariMax with an XtaLAB P200 diffractometer using multi-layer mirror-monochromated Mo K $\alpha$ radiation $(\lambda=0.71075 \AA)$ at $153 \pm 1 \mathrm{~K}$. Data were collected and processed using CrystalClear, CrystalClear-SM Expert for Windows, and structural analysis was performed using CrystalStructure for Windows. The structure was solved by SHELXS-2013 and refined by SHELXL-2014 [12]. For the three platinum-coordinated polyoxoanions, 11 tungsten atoms, 2 platinum atoms, single phosphorus atom (or a silicon atom and a germanium atom), 4 nitrogen atoms, and 39 oxygen atoms were clarified. The three tetramethylammonium ions for TMA-P-Pt and four ions for TMA-Si-Pt and TMA-Ge-Pt were also identified; however, the solvated water molecules could not be modeled due to the disorder of the atoms. Accordingly, the residual electron density was removed using the SQUEEZE routine in PLATON [13]. We noticed that at least two polymorphisms with space group of $P 2_{1} / n$ and $P 2_{1} / c$ were contained in the crystals of TMA-Si-Pt and TMA-Ge-Pt. The crystal data, molecular structures, and unit cell packings are shown in the supporting information.

\subsection{Photocatalytic Reaction}

Typical photocatalytic reactions were carried out at $25^{\circ} \mathrm{C}$. TMA-P-Pt, TMA-Si-Pt, and TMA-Ge-Pt $\left(0.5\right.$ - $2.0 \mu \mathrm{mol}$ of Pt), EY $(2.5 \mu \mathrm{mol}), \mathrm{K}_{5}\left[\alpha-\mathrm{SiW}_{11}\left\{\mathrm{Al}\left(\mathrm{OH}_{2}\right)\right\} \mathrm{O}_{39}\right] \cdot 7 \mathrm{H}_{2} \mathrm{O}$ $(\mathrm{K}-\mathrm{Si}-\mathrm{Al})(2.5 \mu \mathrm{mol})$, and $\mathrm{TiO}_{2}$ (anatase:rutile $\left.=80: 20\right)(50 \mathrm{mg})$ were dissolved in $10 \mathrm{~mL}$ of $100 \mathrm{mM}$ aqueous triethanolamine (TEA) solution at $\mathrm{pH}$ 7.0. The solution was placed into a glass reaction vessel, which was connected to a Pyrex conventional closed gas circulation system $\left(245.5 \mathrm{~cm}^{3}\right)$. The photoreaction was initiated by light irradiation using a $300 \mathrm{~W}$ Xe lamp equipped with a cut-off filter $(\lambda \geq 400 \mathrm{~nm})$. The evolution of $\mathrm{H}_{2}$, $\mathrm{O}_{2}$, $\mathrm{CO}$, and $\mathrm{CH}_{4}$ was analyzed using a gas chromatograph (thermal conductivity detector, Molecular Sieve 5A stainless columns). The samples were assigned after comparison with standard samples analyzed under the same conditions. The turnover number (TON) was calculated as $2\left[\mathrm{H}_{2}\right.$ evolved (mol) $] /[\mathrm{Pt}$ atoms $(\mathrm{mol})]$.

\section{Results and Discussion}

To investigate the influence of central atoms in $\alpha$-Keggin diplatinum(II)-coordinated 
polyoxotungstates on photocatalytic hydrogen evolution, we synthesized two platinum compounds, $\left[\left(\mathrm{CH}_{3}\right)_{4} \mathrm{~N}\right]_{4}\left[\alpha-\mathrm{SiW}_{11} \mathrm{O}_{39}\left\{c i s-\mathrm{Pt}\left(\mathrm{NH}_{3}\right)_{2}\right\}_{2}\right] \cdot 13 \mathrm{H}_{2} \mathrm{O}$ (TMA-Si-Pt) and $\left[\left(\mathrm{CH}_{3}\right)_{4} \mathrm{~N}\right]_{4}\left[\alpha-\mathrm{GeW}_{11} \mathrm{O}_{39}\left\{\text { cis- } \mathrm{Pt}\left(\mathrm{NH}_{3}\right)_{2}\right\}_{2}\right] \cdot 11 \mathrm{H}_{2} \mathrm{O}$ (TMA-Ge-Pt), by a 2:1 stoichiometric reaction of cis-diamminedichloroplatinum(II) (cisplatin) with mono-lacunary Keggin silico- and germanotungstates, $\left[\mathrm{SiW}_{11} \mathrm{O}_{39}\right]^{8-}$ and $\left[\mathrm{GeW}_{11} \mathrm{O}_{39}\right]^{8-}$, in an aqueous solution at $25^{\circ} \mathrm{C}$ under atmospheric conditions, as previously reported for TMA-P-Pt (see supporting information; Scheme S1 and Scheme S2) [5]. TMA-Si-Pt and TMA-Ge-Pt were finally isolated as analytically pure, yellow crystalline powder at $31 \%$ and $44 \%$ yield, respectively. A single crystal of TMA-Si-Pt and TMA-Ge-Pt for X-ray crystallography was obtained by vapor diffusion from water/ethanol at $25^{\circ} \mathrm{C}$. The TMA-P-Pt was successfully crystallized by vapor diffusion from water/acetone at $25^{\circ} \mathrm{C}$.

The elemental analyses results were in good agreement with the calculated values for the chemical formula of TMA-Si-Pt and TMA-Ge-Pt with 13 and 11 hydrated water molecules (see supporting information). The weight loss observed during drying before analysis was $4.42 \%$ and $4.52 \%$ for TMA-Si-Pt and TMA-Ge-Pt, corresponding to nine weakly solvated or adsorbed water molecules. In contrast, during TG/DTA under atmospheric conditions, a weight loss of $6.05 \%$ and $5.22 \%$ was observed below $259.8^{\circ} \mathrm{C}$ and $210.8^{\circ} \mathrm{C}$, corresponding to 13 and 11 water molecules, respectively (Figure S1 and Figure S2). Therefore, the number of water molecules (13) and (11) observed by TG/DTA under atmospheric conditions was consistent with the sum of hydrated water molecules (4) and (2) indicated by elemental analysis and the number of water molecules (9) corresponding to the weight loss observed during drying before analysis. In addition, a weight loss of $10.5 \%$ and $9.89 \%$ was observed in the temperature range from $259.8^{\circ} \mathrm{C}$ to $420^{\circ} \mathrm{C}$ and $210.8^{\circ} \mathrm{C}$ to $403.4^{\circ} \mathrm{C}$, corresponding to the sum of four tetramethylammonium ions and four ammonia molecules, respectively.

The molecular structures and solid-state packings of TMA-P-Pt, TMA-Si-Pt, and TMA-Ge-Pt are illustrated in Figures S3-S12. Selected bond lengths and angles around the platinum centers are summarized in Tables S1-S5. For the all compounds, the three and four tetramethylammonium ions were observed by X-ray crystallography; however, the hydrated water molecules could not be identified because of the disorder. The X-ray crystallography of these platinum compounds revealed that the two cis-platinum(II) moieties, $\left[\text { cis- } \mathrm{Pt}\left(\mathrm{NH}_{3}\right)_{2}\right]^{2+}$, were coordinated each to the two oxygen atoms in a mono-vacant site of $\left[\mathrm{XW}_{11} \mathrm{O}_{39}\right]^{(12-\mathrm{n})-}\left(\mathrm{X}^{\mathrm{n}+}=\mathrm{Si}^{4+}, \mathrm{Ge}^{4+}, \mathrm{P}^{5+}\right)$, as previously reported for Cs-P-Pt [6]. The TMA-Si-Pt and TMA-Ge-Pt crystals contained at least two polymorphisms with space group of $P 2_{1} / n$ and $P 2_{1} / c$, while the TMA-P-Pt and Cs-P-Pt crystals did not contain polymorphisms for at least a dozen measurements.

The FTIR spectra of TMA-Si-Pt and TMA-Ge-Pt measured as $\mathrm{KBr}$ disks are shown in Figure S13 and Figure S14. The spectral patterns of TMA-Si-Pt (1006, 950, 892, 875, 840, 790, 734, 708, and $524 \mathrm{~cm}^{-1}$ ) and TMA-Ge-Pt (958, 950, 876, 839, 816, 790, 768, 717,697 , and $\left.526 \mathrm{~cm}^{-1}\right)$ were different from those of $\mathrm{K}_{8}\left[\mathrm{SiW}_{11} \mathrm{O}_{39}\right] \cdot 17 \mathrm{H}_{2} \mathrm{O}(997,961$, 896, 799, 733, 539, and $\left.515 \mathrm{~cm}^{-1}\right)$ and $\mathrm{K}_{6} \mathrm{Na}_{2}\left[\mathrm{GeW}_{11} \mathrm{O}_{39}\right] \cdot 12 \mathrm{H}_{2} \mathrm{O}(957,880,848,799,720$, 518 , and $466 \mathrm{~cm}^{-1}$ ), suggesting that the two platinum(II) moieties were coordinated to 
the vacant site of $\left[\mathrm{SiW}_{11} \mathrm{O}_{39}\right]^{8-}$ and $\left[\mathrm{GeW}_{11} \mathrm{O}_{39}\right]^{8-}$.

The ${ }^{1} \mathrm{H}$ NMR spectra of TMA-Si-Pt in DMSO- $d_{6}$ showed two signals at $4.33 \mathrm{ppm}$ and $4.37 \mathrm{ppm}$ with 1:1 intensities (Figure S15). As previously reported for TMA-P-Pt and Cs-P-Pt, the two ${ }^{1} \mathrm{H}$ signals were due to the two sets of $\mathrm{NH}_{3}$ ligands coordinated to the platinum sites [5] [6]. For TMA-Ge-Pt, a broad signal was observed at $4.37 \mathrm{ppm}$ because of an overlap of the two signals of $\mathrm{NH}_{3}$ ligands (Figure S16).

The UV-Vis spectra (Figure S17 and Figure S18) of TMA-Si-Pt and TMA-Ge-Pt in water showed two broad absorption bands at $322 \mathrm{~nm}\left(\varepsilon 6775 \mathrm{M}^{-1} \mathrm{~cm}^{-1}\right)$ and $406 \mathrm{~nm}(\varepsilon$ $\left.1223 \mathrm{M}^{-1} \mathrm{~cm}^{-1}\right)$, and $323 \mathrm{~nm}\left(\varepsilon 7204 \mathrm{M}^{-1} \mathrm{~cm}^{-1}\right)$ and $409 \mathrm{~nm}\left(\varepsilon 1087 \mathrm{M}^{-1} \mathrm{~cm}^{-1}\right)$. The bands at $322 \mathrm{~nm}$ and $323 \mathrm{~nm}$ were assigned to the charge transfer bands of W-O and a broad band at $406 \mathrm{~nm}$ and $409 \mathrm{~nm}$ due to the two platinum(II) atoms, as previously reported for TMA-P-Pt and Cs-P-Pt [5] [6].

The photocatalytic activities of TMA-P-Pt, TMA-Si-Pt, and TMA-Ge-Pt at 0.5, 1.0, and $2.0 \mu \mathrm{mol} P t$ were determined for the evolution of hydrogen from $100 \mathrm{mM}$ aqueous TEA solution ( $\mathrm{pH} 7.0)$ under light irradiation $(\lambda \geq 400 \mathrm{~nm})$ in the presence of EY, $\mathrm{K}-\mathrm{Si}-\mathrm{Al}$, and $\mathrm{TiO}_{2}$. Here, TEA was employed as an electron donor. During the photoreactions, the platinum and aluminum compounds and $\mathrm{EY}$ were soluble in the aqueous TEA solution. Hydrogen was formed with $100 \%$ selectivity, and $\mathrm{O}_{2}, \mathrm{CO}_{2}, \mathrm{CO}$, and $\mathrm{CH}_{4}$ were not detected under these reaction conditions. For the three platinum compounds, the amount of hydrogen increased with time, as shown in Figure 1 and Figure S19. In the platinum range of $0.5-2.0 \mu \mathrm{mol}$, the order of TONs after $5 \mathrm{~h}$ was TMA-P-Pt > TMA-Ge-Pt > TMA-Si-Pt, as shown in Table 1 .

To determine whether the amounts of HPB anions of TMA-P-Pt, TMA-Si-Pt, and TMA-Ge-Pt were influenced by the central atoms or not, UV-Vis spectra of a mixture of EY $(2.5 \mu \mathrm{mol})$ and platinum compounds $(2.0 \mu \mathrm{mol} \mathrm{Pt})$ were observed in $100 \mathrm{mM}$ aqueous TEA solution at $\mathrm{pH} 7(10 \mathrm{~mL})$ under the light irradiation $(\lambda \geq 400 \mathrm{~nm})$.
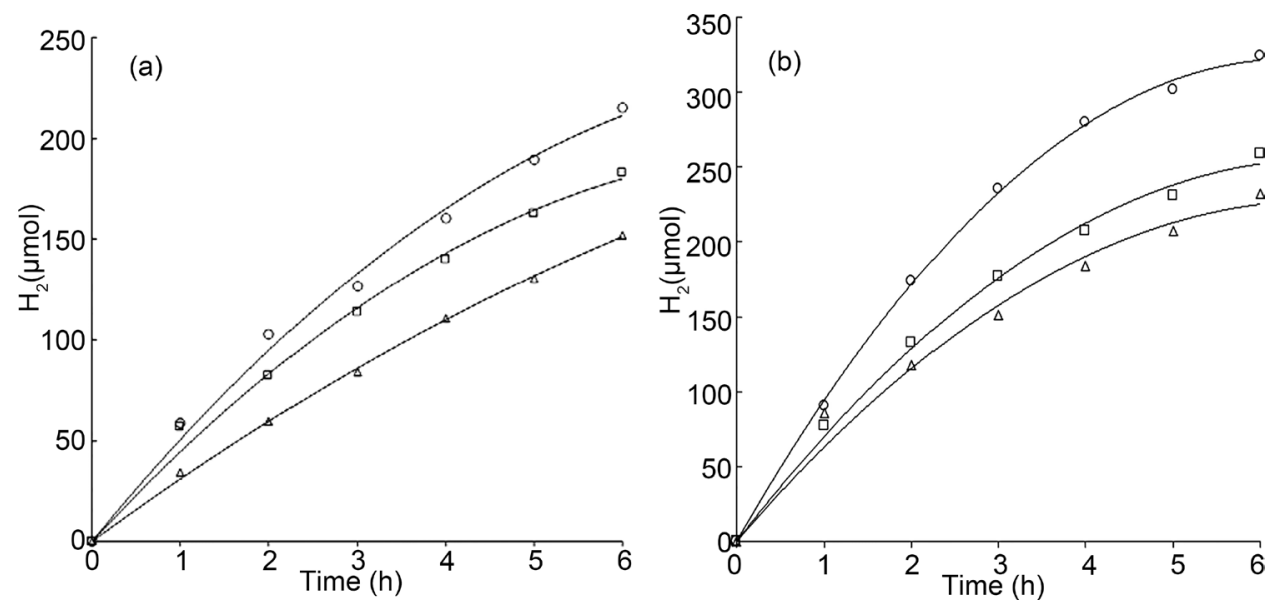

Figure 1. Time course for hydrogen evolution from aqueous triethanolamine (TEA) solution under visible light irradiation. Reaction conditions: TMA-P-Pt $(\mathrm{O})$, TMA-Si-Pt $(\Delta)$, and TMA-Ge-Pt ( $\square$ ) ((a) $0.5 \mu \mathrm{mol}$ and (b) $2.0 \mu \mathrm{mol}$ of Pt), EY $(2.5 \mu \mathrm{mol}), \mathrm{K}-\mathrm{Si}-\mathrm{Al}(2.5 \mu \mathrm{mol}), \mathrm{TiO}_{2}$ (anatase:rutile $=80: 20) 50 \mathrm{mg}, 100 \mathrm{mM}$ TEA aqueous solution $(10 \mathrm{~mL}, \mathrm{pH}$ ), light irradiation at $\lambda \geq 400 \mathrm{~nm}$ at $25^{\circ} \mathrm{C}$. 
Table 1. Hydrogen evolution from aqueous triethanolamine (TEA) solution under visible light irradiation $^{\mathrm{a}}$.

\begin{tabular}{|c|c|c|c|}
\hline Pt complexes ( $\mu \mathrm{mol}$ of Pt atom) & Reaction time (h) & $\mathrm{H}_{2}(\mu \mathrm{mol})$ & $\mathrm{TON}^{\mathrm{b}}$ \\
\hline \multirow{2}{*}{ TMA-P-Pt $(0.5)$} & 1 & 58.7 & 235 \\
\hline & 5 & 189.4 & 758 \\
\hline \multirow{2}{*}{ TMA-Si-Pt (0.5) } & 1 & 34.3 & 137 \\
\hline & 5 & 130.4 & 522 \\
\hline \multirow{2}{*}{ TMA-Ge-Pt (0.5) } & 1 & 57.0 & 228 \\
\hline & 5 & 162.9 & 651 \\
\hline \multirow{2}{*}{ TMA-P-Pt (1.0) } & 1 & 84.6 & 167 \\
\hline & 5 & 252.6 & 505 \\
\hline \multirow{2}{*}{ TMA-Si-Pt (1.0) } & 1 & 56.0 & 112 \\
\hline & 5 & 166.2 & 332 \\
\hline \multirow{2}{*}{ TMA-Ge-Pt (1.0) } & 1 & 76.7 & 153 \\
\hline & 5 & 193.8 & 388 \\
\hline \multirow{2}{*}{ TMA-P-Pt (2.0) } & 1 & 90.2 & 90 \\
\hline & 5 & 301.4 & 301 \\
\hline \multirow{2}{*}{ TMA-Si-Pt (2.0) } & 1 & 86.1 & 86 \\
\hline & 5 & 207.5 & 208 \\
\hline \multirow{2}{*}{ TMA-Ge-Pt (2.0) } & 1 & 77.6 & 78 \\
\hline & 5 & 230.6 & 231 \\
\hline \multirow{2}{*}{ TMA-P-Pt $(2.0)^{\mathrm{c}}$} & 1 & 50.4 & 50 \\
\hline & 5 & 125.0 & 125 \\
\hline \multirow{2}{*}{ TMA-Si-Pt $(2.0)^{\mathrm{c}}$} & 1 & 35.1 & 35 \\
\hline & 5 & 79.3 & 79 \\
\hline \multirow{2}{*}{ TMA-Ge-Pt $(2.0)^{\mathrm{c}}$} & 1 & 47.9 & 48 \\
\hline & 5 & 102.4 & 102 \\
\hline
\end{tabular}

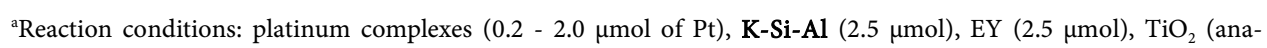
tase:rutile $=80: 20) 50 \mathrm{mg}, 100 \mathrm{mM}$ TEA aq. soln. $(\mathrm{pH} 7 ; 10 \mathrm{~mL}), 25^{\circ} \mathrm{C}$, light $(\lambda \geq 400 \mathrm{~nm})$; ${ }^{\text {b Turnover number }}$ $(\mathrm{TON})=2\left[\mathrm{H}_{2}\right.$ evolved $\left.(\mathrm{mol})\right] /[\mathrm{Pt}$ atoms $(\mathrm{mol})] ;{ }^{\mathrm{c}}$ Without $\mathrm{TiO}_{2}$.

Before light irradiation, all spectra were the same as those of EY; thus, the bands of the platinum compounds were not observed because they were hidden by large bands of EY. During the light irradiation, a large band at approximately $520 \mathrm{~nm}$ was sifted to approximately $490 \mathrm{~nm}$, which was assigned to a fluorescein-like species, as previously reported [14] [15]. The shift was observed after at least $0.5 \mathrm{~h}$ of light irradiation, and the absorbance gradually decreased with time. We noticed that the rates of decrease in absorbance for TMA-Ge-Pt were much slower than those for TMA-P-Pt and TMA-Si-Pt (Figure 2). Thus, a decomposition of fluorescein-like species was the most restrained in the presence of TMA-Ge-Pt. In contrast, a new broad band due to HPB was observed at around 650, 648, and $654 \mathrm{~nm}$ under light irradiation (Figure 3) 
[8] [16]. During $4 \mathrm{~h}$ of light irradiation, the absorbance of HPB formed by reduction of W(VI) sites in the platinum compounds increased with time, decreasing in the order TMA-P-Pt $>$ TMA-Ge-Pt $>$ TMA-Si-Pt, which is consistent with that of hydrogen generation. In contrast, the absorbance of HPB in TMA-P-Pt and TMA-Si-Pt

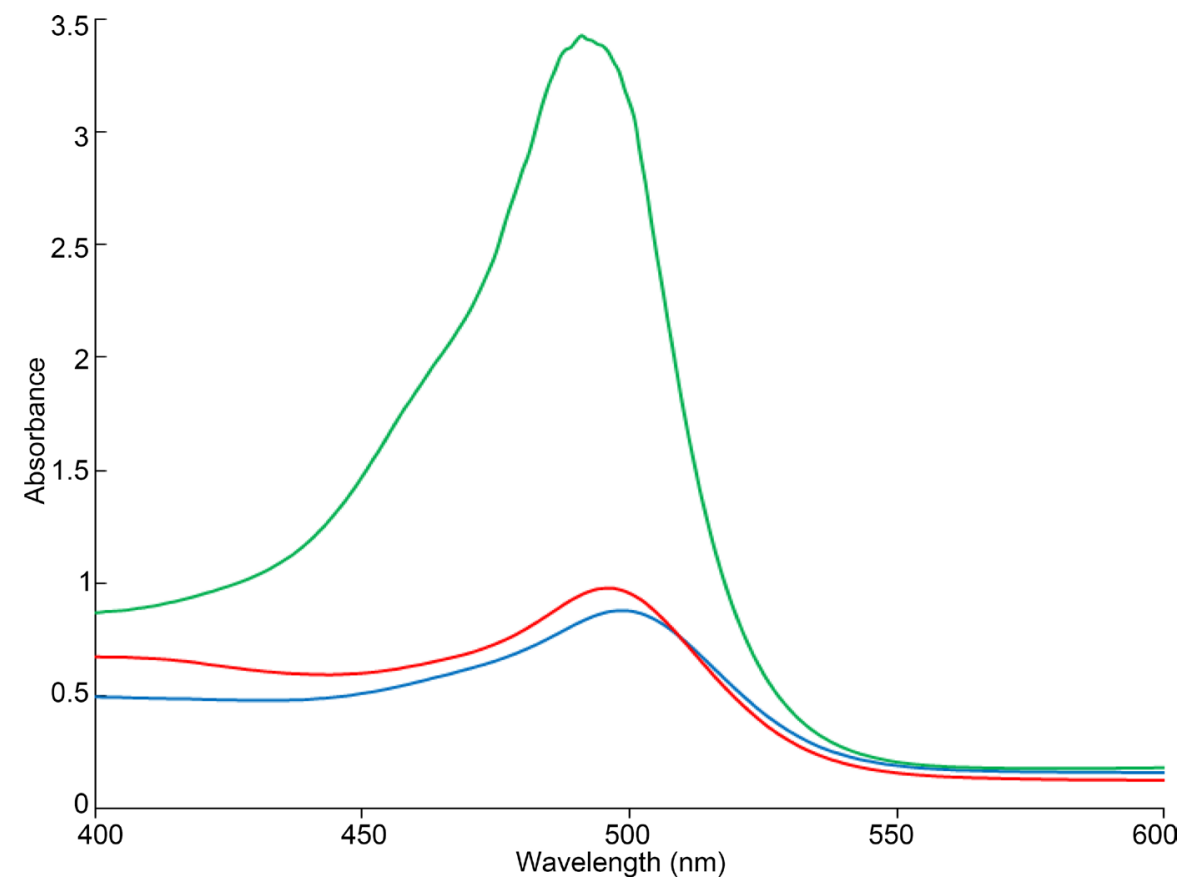

Figure 2. UV-vis spectra in $100 \mathrm{mM}$ aqueous triethanolamine (TEA) solution at $\mathrm{pH} 7$ of a mixture of platinum compounds $\left(1.0 \times 10^{-4} \mathrm{M}\right)$ and $\mathrm{EY}\left(2.5 \times 10^{-4} \mathrm{M}\right)$ after $5 \mathrm{~h}$ of light irradiation $(\lambda$ $\geq 400 \mathrm{~nm}$ ). The fluorescein-like species were observed at around $490 \mathrm{~nm}$ for TMA-P-Pt (blue line), TMA-Si-Pt (red), and TMA-Ge-Pt (green).
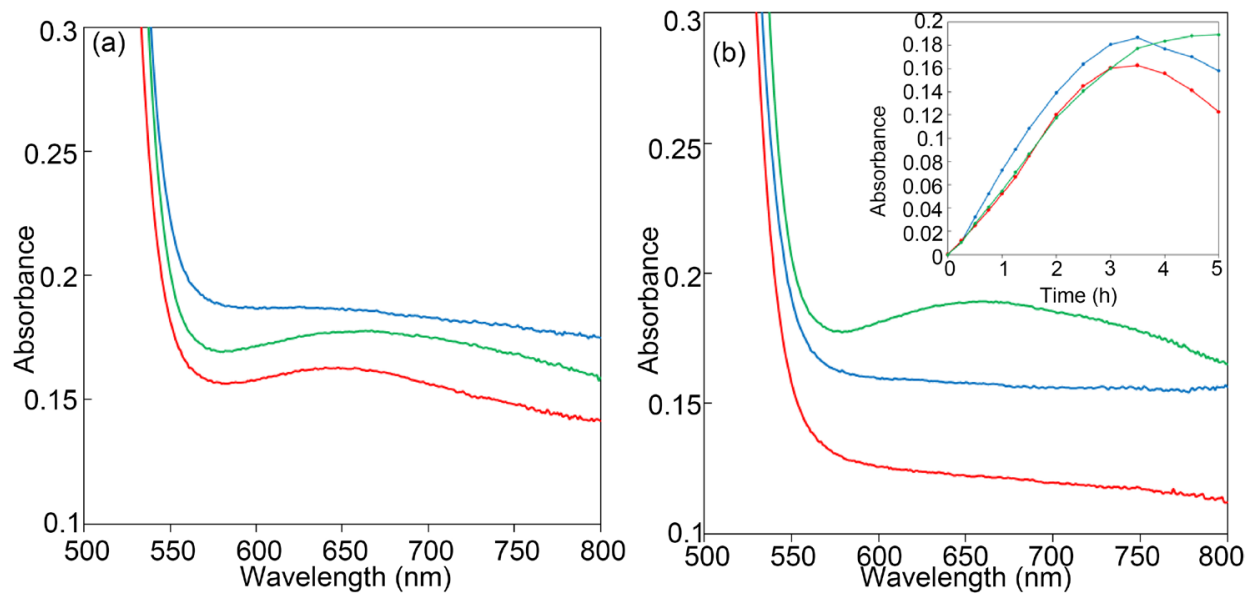

Figure 3. (a) UV-vis spectra in $100 \mathrm{mM}$ aqueous triethanolamine (TEA) solution at $\mathrm{pH} 7 \mathrm{of}$ a mixture of platinum compounds $\left(1.0 \times 10^{-4} \mathrm{M}\right)$ and EY $\left(2.5 \times 10^{-4} \mathrm{M}\right)$ after (a) $3.5 \mathrm{~h}$ and (b) $5 \mathrm{~h}$ of light irradiation $(\lambda \geq 400 \mathrm{~nm})$. The HPB were observed at around 650, 648, and $654 \mathrm{~nm}$ for TMA-P-Pt (blue line), TMA-Si-Pt (red), and TMA-Ge-Pt (green). Inset: a plot of absorbance observed at 650,648 , and $654 \mathrm{~nm}$ with time. 
decreased after $5 \mathrm{~h}$ of light irradiation, and the order of absorbance changed to TMA-Ge-Pt > TMA-P-Pt > TMA-Si-Pt. The decrease of absorbance might be due to the lifetime of HPB and/or the remaining amounts of fluorescein-like species. However, the order of photocatalytic activities did not change during $5 \mathrm{~h}$ of irradiation even under the same reaction conditions as those of UV-vis measurements (Table 1). Thus, the photocatalytic activities of platinum compounds were not decided by the amounts of sensitizers alone (i.e., fluorescein-like species and HPB anions, under the present reaction conditions).

Here, the cyclic voltammograms of TMA-P-Pt, TMA-Si-Pt, and TMA-Ge-Pt were measured in $0.1 \mathrm{M} \mathrm{NaClO}_{4}$ aqueous solution ( $\mathrm{pH} \mathrm{5.5)}$ at a scan rate of $100 \mathrm{mV} / \mathrm{s}$ (Figure 4). The TMA-P-Pt and TMA-Ge-Pt had two reduction potentials (values at the maximum of the first and second reduction waves) at $(-0.837$ and $-1.05 \mathrm{~V})$ and $(-1.02$ and $-1.31 \mathrm{~V}$ ) in the potential range from 0.0 to $-1.5 \mathrm{~V}$, and TMA-Si-Pt showed a reduction potential at approximately $-1.07 \mathrm{~V}$; these are likely one-electron reduction of $\mathrm{W}(\mathrm{VI})$ sites at $\mathrm{pH} 5.5$ [17]. These redox pairs were reproducible in multiple scans at scan rates of 10-300 $\mathrm{mV} / \mathrm{s}$, revealing that the platinum compounds were stable during the reversible redox processes. This was also supported by the result that no clear deactivation was observed during $6 \mathrm{~h}$ of light irradiation (Figure 1). These results suggest that a slower decrease of absorbance observed in TMA-Ge-Pt after $5 \mathrm{~h}$ of light irradiation was not due to the stability of platinum compounds. When mono-lacunary

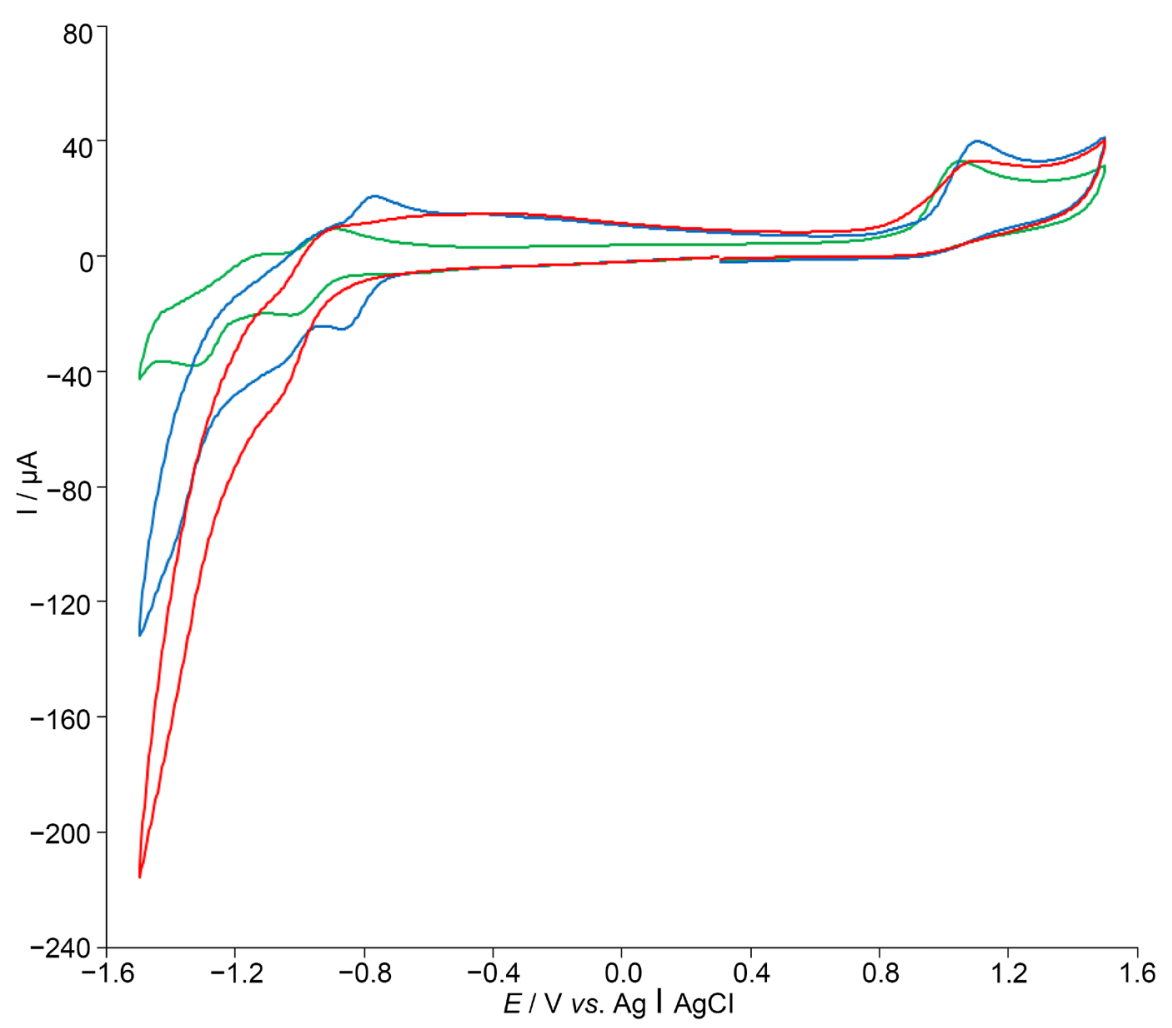

Figure 4. Cyclic voltammograms in $0.1 \mathrm{M} \mathrm{NaClO}_{4}$ (pH 5.5) of TMA-P-Pt (blue line), TMA-Si-Pt (red), and TMA-Ge-Pt (green) at a scan rate of $100 \mathrm{mV} / \mathrm{s}$. 
Keggin-type polyoxotungstates $\left[\mathrm{XW}_{11} \mathrm{O}_{39}\right]^{(12-\mathrm{n})-}\left(\mathrm{X}^{\mathrm{n+}}=\mathrm{Si}^{4+}, \mathrm{Ge}^{4+}, \mathrm{P}^{5+}\right)$ were used instead of platinum compounds under the same reaction conditions as those of UV-Vis measurements, a remarkable difference in the UV-Vis spectra of $\left[\mathrm{GeW}_{11} \mathrm{O}_{39}\right]^{8-}$ was not observed during 5-h light irradiation. These results suggested that a coordination of cis-platinum(II) moieties to the mono-vacant site in Keggin-type germanotungstate caused a specific influence to a decomposition of fluorescein-like species, and a long-lived fluorescein-like species could cause a slower decrease of absorbance of HPB in TMA-Ge-Pt. Further studies into these reaction mechanisms are in progress, and we will report the results in due course.

\section{Summary}

Monomeric diplatinum complexes composed of mono-lacunary $\alpha$-Keggin silico- and germanotungstates were synthesized and characterized by $\mathrm{X}$-ray structure analysis, elemental analysis, TG/DTA, FTIR, cyclic voltammetry, UV-Visible, and ${ }^{1} \mathrm{H}$ solution NMR spectroscopy. We successfully obtained single crystals of tetramethylammonium salts $\left[\left(\mathrm{CH}_{3}\right)_{4} \mathrm{~N}\right]_{4}\left[\alpha-\mathrm{SiW}_{11} \mathrm{O}_{39}\left\{c i s-\mathrm{Pt}\left(\mathrm{NH}_{3}\right)_{2}\right\}_{2}\right] \cdot 13 \mathrm{H}_{2} \mathrm{O}$ (TMA-Si-Pt) and $\left[\left(\mathrm{CH}_{3}\right)_{4} \mathrm{~N}\right]_{4}\left[\alpha-\mathrm{GeW}_{11} \mathrm{O}_{39}\left\{c i s-\mathrm{Pt}\left(\mathrm{NH}_{3}\right)_{2}\right\}_{2}\right] \cdot 11 \mathrm{H}_{2} \mathrm{O}$ (TMA-Ge-Pt) by reacting cisplatin with mono-lacunary $\alpha$-Keggin polyoxoanions, followed by vapor diffusion from water/ethanol. The crystals of TMA-Si-Pt and TMA-Ge-Pt contained at least two polymorphisms with space group of $P 2_{1} / n$ and $P 2_{1} / c$. Furthermore, single crystals of a tetramethylammonium salt of $\alpha$-Keggin diplatinum-coordinated phosphotungstate $\left[\left(\mathrm{CH}_{3}\right)_{4} \mathrm{~N}\right]_{3}\left[\mathrm{PW}_{11} \mathrm{O}_{39}\left\{\text { cis- } \mathrm{Pt}\left(\mathrm{NH}_{3}\right)_{2}\right\}_{2}\right] \cdot 10 \mathrm{H}_{2} \mathrm{O}$ (TMA-P-Pt) were obtained via vapour diffusion from water/acetone, and polymorphism was not observed under the present conditions. Single-crystal X-ray structure analyses of the three platinum compounds revealed that the two cis-platinum(II) moieties, $\left[\text { cis- } \mathrm{Pt}\left(\mathrm{NH}_{3}\right)_{2}\right]^{2+}$, were coordinated each to two oxygen atoms in a mono-vacant site of $\left[\mathrm{XW}_{11} \mathrm{O}_{39}\right]^{(12-\mathrm{n})-}\left(\mathrm{X}^{\mathrm{n}+}=\mathrm{Si}^{4+}, \mathrm{Ge}^{4+}, \mathrm{P}^{5+}\right)$. The three platinum compounds exhibited hydrogen evolution from aqueous TEA solution under visible light irradiation $(\lambda \geq 400 \mathrm{~nm})$ in the presence of eosin $\mathrm{Y}, \alpha$-Keggin mono-aluminum-substituted silicotungstate, and titanium dioxide. The order of photocatalytic activities was TMA-P-Pt > TMA-Ge-Pt > TMA-Si-Pt; thus, the central atoms in platinum compounds affected the photocatalytic activities. The rates of fluoresceinlike species decomposition and the amounts of HPB anions were also influenced by the central atoms, and TMA-Ge-Pt exhibited a specific influence. However, the order of rates in fluorescein-like species decomposition and amounts of HPB anions did not necessarily accord with that of photocatalytic activities under the present reaction conditions.

\section{Acknowledgements}

This work was supported by the Ministry of Education, Culture, Sports, Science and Technology of Japan. We also acknowledge Mr. Hattori (Shizuoka University) for preliminary experiments regarding the synthesis and crystallization of TMA-P-Pt and TMA-Si-Pt. 


\section{References}

[1] Abe, R. (2010) Recent Progress on Photocatalytic and Photoelectrochemical Water Splitting under Visible Light Irradiation. Journal of Photochemistry and Photobiology C: Photochemistry Reviews, 11, 179-209. http://dx.doi.org/10.1016/j.jphotochemrev.2011.02.003

[2] Maeda, K. and Domen, K. (2010) Photocatalytic Water Splitting: Recent Progress and Future Challenges. The Journal of Physical Chemistry Letters, 1, 2655-2661. http://dx.doi.org/10.1021/jz1007966

[3] Hisatomi, T., Kubota, J. and Domen, K. (2014) Recent Advances in Semiconductors for Photocatalytic and Photoelectrochemical Water Splitting. Chemical Society Reviews, 43, 7520-7535. http://dx.doi.org/10.1039/C3CS60378D

[4] Yang, J., Wang, D., Han, H. and Li, C. (2013) Roles of Cocatalysts in Photocatalysis and Photoelectrocatalysis. Accounts of Chemical Research, 46, 1900-1090. http://dx.doi.org/10.1021/ar300227e

[5] Kato, M. and Kato, C.N. (2011) A Keggin-Type Polyoxotungstate-Coordinated Diplatinum(II) Complex: Synthesis, Characterization, and Stability of the Cis-Platinum(II) Moieties in Dimethylsulfoxide and Water. Inorganic Chemistry Communications, 14, 982-985. http://dx.doi.org/10.1016/j.inoche.2011.03.049

[6] Kato, C.N., Morii, Y., Hattori, S., Nakayama, R., Makino, Y. and Uno, H. (2012) Diplatinum(II)-Coordinated Polyoxotungstate: Synthesis, Molecular Structure, and Photocatalytic Performance for Hydrogen Evolution from Water under Visible-Light Irradiation. Dalton Transactions, 41, 10021-10027. http://dx.doi.org/10.1039/c2dt30915g

[7] Hattori, S., Ihara, Y. and Kato, C.N. (2015) A Novel Photocatalytic System Constructed Using Eosin Y, Titanium Dioxide, and Keggin-Type Platinum(II)- and Aluminum(III)-Coordinated Polyoxotungstates for Hydrogen Production from Water Under Visible Light Irradiation. Catalysis Letters, 145, 1703-1709. http://dx.doi.org/10.1007/s10562-015-1574-8

[8] Fu, N. and Lu, G. (2009) Photo-Catalytic $\mathrm{H}_{2}$ Evolution over a Series of Keggin-Structure Heteropoly Blue Sensitized $\mathrm{Pt} / \mathrm{TiO}_{2}$ under Visible Light Irradiation. Applied Surface Science, 255, 4378-4383. http://dx.doi.org/10.1016/j.apsusc.2008.11.056

[9] Nie, Y., Chen, W., Liu, Z. and Wang, E. (2015) Synthesis and Photocatalytic Hydrogen Evolution Activity of Three Keggin-Type Polyoxometalates with Different Central Atoms. Inorg. Chemical Communications, 61, 184-186. http://dx.doi.org/10.1016/j.inoche.2015.09.015

[10] Tézé, A. and Hervé, G. (1977) Formation et isomerisation des undeca et dodeca tungstosilicates et germanates isomeres. Journal of Inorganic and Nuclear Chemistry, 39, 999-1002. http://dx.doi.org/10.1016/0022-1902(77)80251-0

[11] Haraguchi, N., Okaue, Y., Isobe, T. and Matsuda, Y. (1994) Stabilization of Tetravalent Cerium upon Coordination of Unsaturated Heteropolytungstate Anions. Inorganic Chemistry, 33, 1015-1020. http://dx.doi.org/10.1021/ic00084a008

[12] Sheldrick, G.M. (2008) A Short History of SHELX. Acta Crystallographica, A64, 112-122. http://dx.doi.org/10.1107/S0108767307043930

[13] Spek, A.L. (2009) Structure Validation in Chemical Crystallography. Acta Crystallographica, D65, 148-155. http://dx.doi.org/10.1107/S090744490804362X

[14] Liu, X., Li, Y., Peng S., Lu, G. and Li, S. (2012) Photocatalytic Hydrogen Evolution under Visible Light Irradiation by the Polyoxometalate $\alpha$-[AlSiW $\left.\mathrm{Al}_{11}\left(\mathrm{H}_{2} \mathrm{O}\right) \mathrm{O}_{39}\right]^{5-}$-Eosin Y System. International Journal of Hydrogen Energy, 37, 12150-12157. http://dx.doi.org/10.1016/j.ijhydene.2012.06.028 
[15] Kimura, K., Miwa, T. and Imamura, M. (1970) Radiolysis and Photolysis of Methanolic Solutions of Eosin. I. The $\gamma$-Radiolysis of Neutral and Alkaline Solutions. Bulletin of the Chemical Society of Japan, 43, 1329-1336. http://dx.doi.org/10.1246/bcsj.43.1329

[16] Papaconstantinou, E. (1989) Photochemistry of Polyoxometalates of Molybdenum and Tungsten and/or Vanadium. Chemical Society Reviews, 18, 1-31.

http://dx.doi.org/10.1039/cs9891800001

[17] Sadakane M. and Steckhan E. (1998) Electrochemical Properties of Polyoxometalates as Electrocatalysts. Chemical Reviews, 98, 219-237. http://dx.doi.org/10.1021/cr960403a 


\section{Supporting Information}

Synthesis and crystallization of $\left[\left(\mathrm{CH}_{3}\right)_{4} \mathrm{~N}\right]_{4}\left[\alpha-\mathrm{SiW}_{11} \mathrm{O}_{39}\left\{\text { cis- } \mathrm{Pt}\left(\mathrm{NH}_{3}\right)_{2}\right\}_{2}\right] \cdot 13 \mathrm{H}_{2} \mathrm{O}$

(TMA-Si-Pt): $\mathrm{K}_{8}\left[\mathrm{SiW}_{11} \mathrm{O}_{39}\right] \cdot 17 \mathrm{H}_{2} \mathrm{O}(0.659 \mathrm{~g} ; 0.20 \mathrm{mmol})$ was added to a solution of cis- $\mathrm{Pt}\left(\mathrm{NH}_{3}\right)_{2} \mathrm{Cl}_{2}(0.120 \mathrm{~g} ; 0.40 \mathrm{mmol})$ dissolved in $160 \mathrm{~mL}$ of water at $70^{\circ} \mathrm{C}$. After stirring for $4 \mathrm{~h}$ at $70^{\circ} \mathrm{C}$, a yellow precipitate was formed. The yellow precipitate was removed off through a membrane filter (JG $0.2 \mu \mathrm{m})$, and solid $\left(\mathrm{CH}_{3}\right)_{4} \mathrm{NCl}(13.152 \mathrm{~g} ; 120$ $\mathrm{mmol}$ ) was added to the filtrate, and stirred for two days at $25^{\circ} \mathrm{C}$. Then, a yellow precipitate was collected by a membrane filter (JG $0.2 \mu \mathrm{m}$ ). For purification, the crude product was dissolved in $\mathrm{H}_{2} \mathrm{O}\left(5 \mathrm{~mL}\right.$ of water per $100 \mathrm{mg}$ of crude product) at $70^{\circ} \mathrm{C}$, followed by crystallization from ethanol at $25^{\circ} \mathrm{C}$. A yellow precipitate was collected by a membrane filter (JG $0.2 \mu \mathrm{m})$. The obtained product was dissolved in water $(15 \mathrm{~mL}$ of water per $100 \mathrm{mg}$ of product) at $70^{\circ} \mathrm{C}$, and crystallized from ethanol at $25^{\circ} \mathrm{C}$ again. The obtained product was $0.1145 \mathrm{~g}$ (the yield calculated on the basis of [mol of TMA-Si-Pt]/ [mol of $\left.\mathrm{K}_{8}\left[\mathrm{SiW}_{11} \mathrm{O}_{39}\right] \cdot 17 \mathrm{H}_{2} \mathrm{O}\right] \times 100$ was $31 \%$ ). For the X-ray crystal measurement, the crystals were obtained by vapor diffusion from water $(1-1.5 \mathrm{~mL}$ of water per $10 \mathrm{mg}$

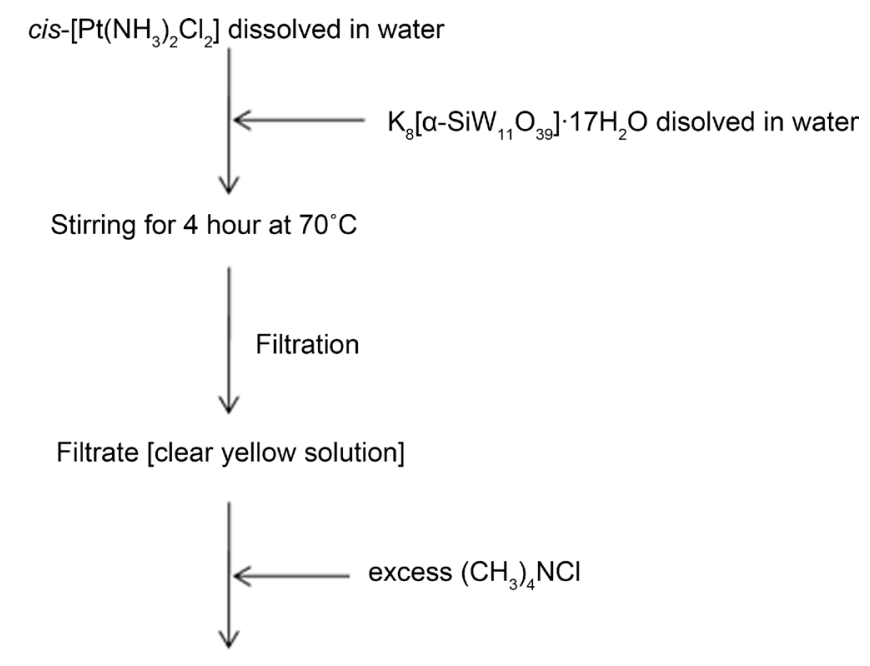

Stirring for 2 days at $25^{\circ} \mathrm{C}$

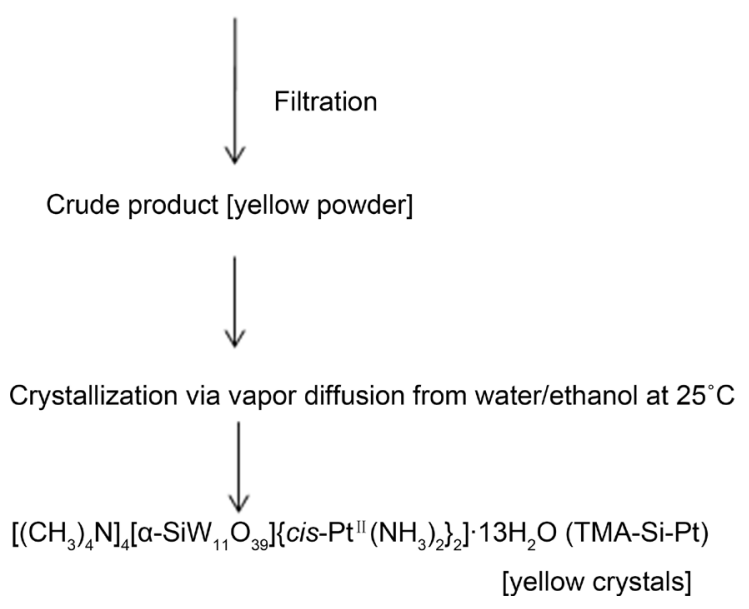

Scheme S1. Synthetic diagram of TMA-Si-Pt. 


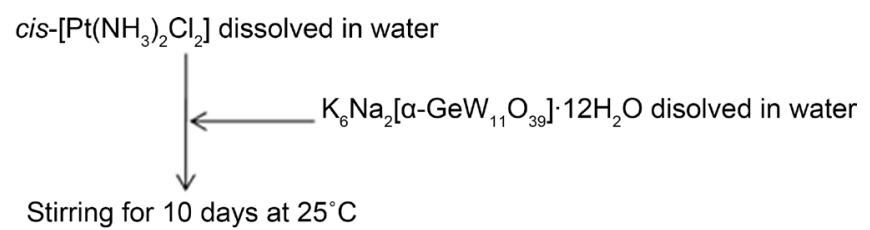

Filtration

Filtrate [clear yellow solution]

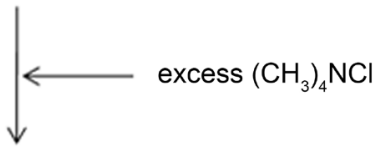

Stirring for $3 \mathrm{~h}$ in an ice bath

Filtration

Washing with ethanol

Crude product [yellow powder]

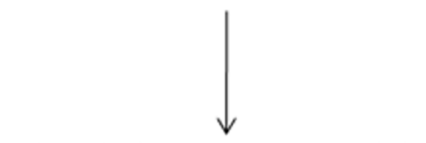

Precipitation from water at $70^{\circ} \mathrm{C}$

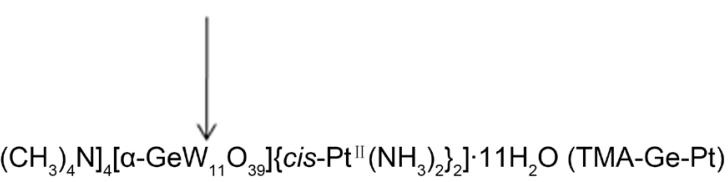

[yellow crystals]

Scheme S2. Synthetic diagram of TMA-Ge-Pt.

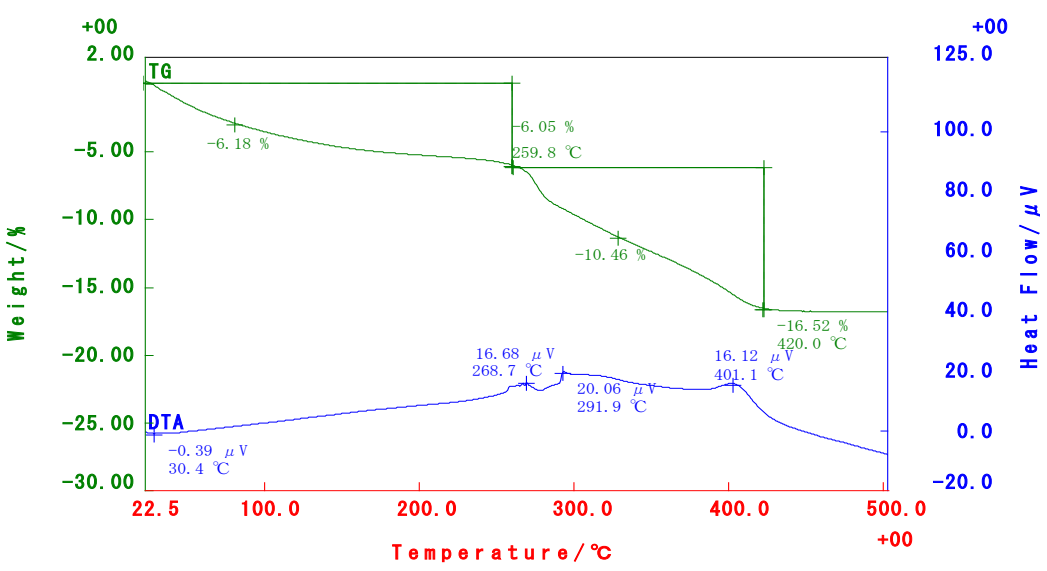

Figure S1. TG/DTA data of TMA-Si-Pt. 


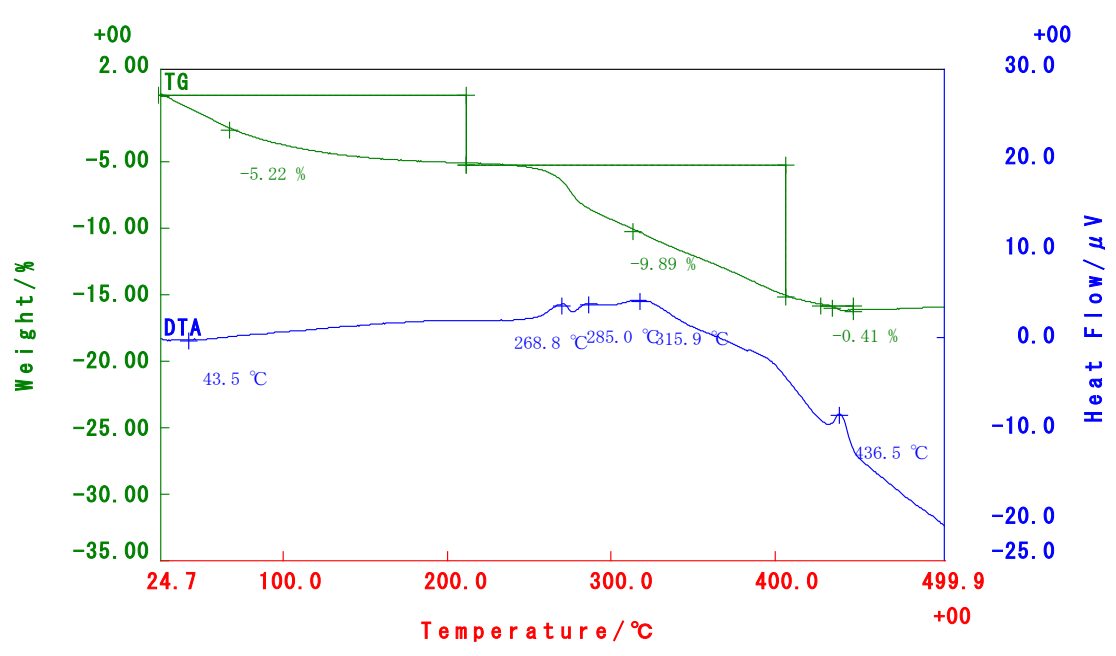

Figure S2. TG/DTA data of TMA-Ge-Pt.

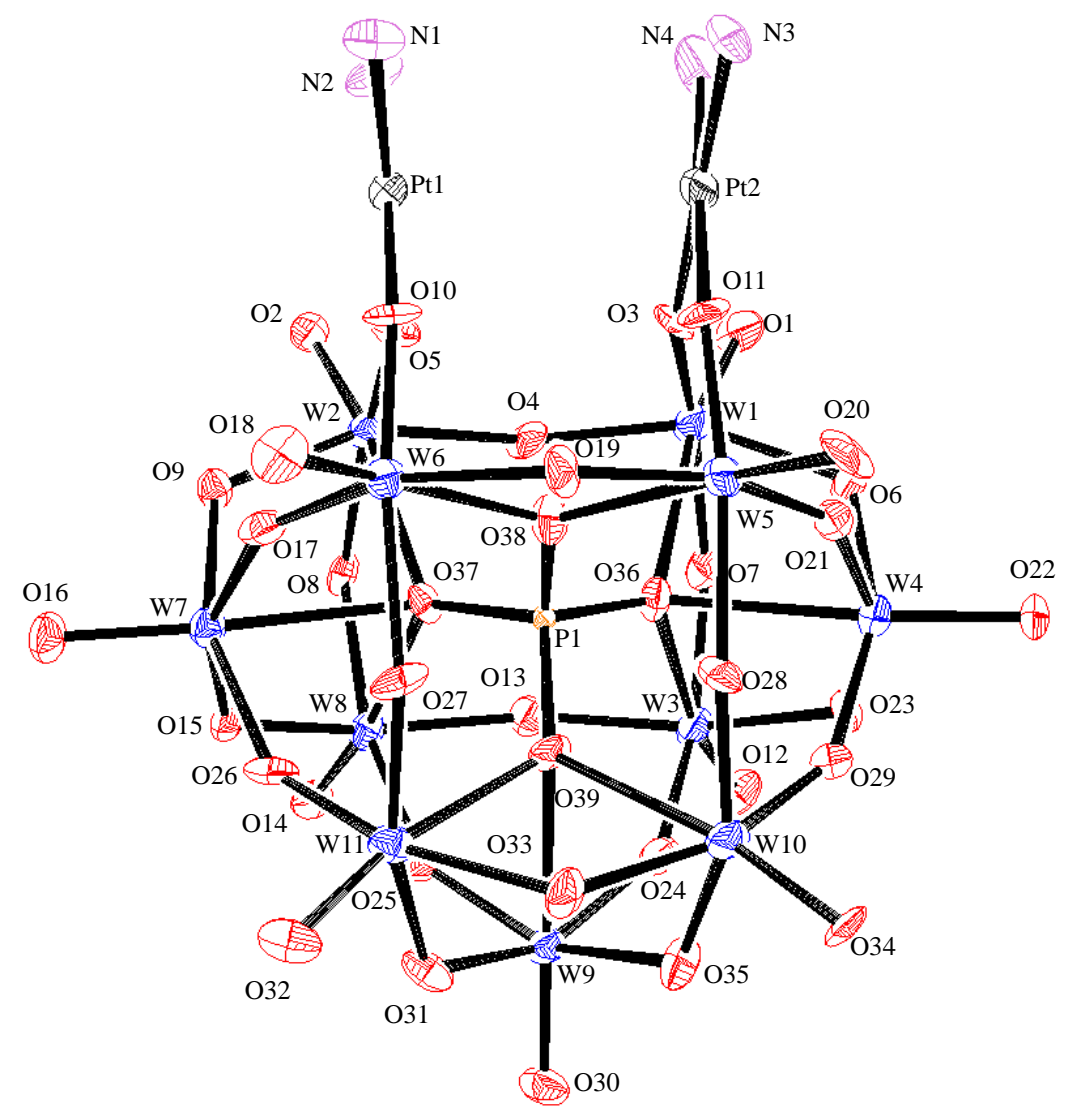

Figure S3. Molecular structure (ORTEP drawing) of TMA-P-Pt.

of product)/ethanol at $25^{\circ} \mathrm{C}$. Elemental analysis results showed: $\mathrm{C}, 5.21 ; \mathrm{H}, 2.01 ; \mathrm{N}, 3.06$; $\mathrm{Si}, 0.78$; Pt, 11.3\%. Calculations for $\left[\left(\mathrm{CH}_{3}\right)_{4} \mathrm{~N}\right]_{4}\left[\mathrm{SiW}_{11} \mathrm{O}_{39}\left\{\text { cis- } \mathrm{Pt}\left(\mathrm{NH}_{3}\right)_{2}\right\}_{2}\right] \cdot \mathrm{xH}_{2} \mathrm{O}(\mathrm{x}=4)=$ $\mathrm{C}_{16} \mathrm{H}_{68} \mathrm{~N}_{8} \mathrm{Pt}_{2} \mathrm{O}_{43} \mathrm{Si}_{1} \mathrm{~W}_{11}$ : C, 5.49; H, 1.96; N, 3.20; Si, 0.80; Pt, 11.14\%. A weight loss of 4.42\% was observed during overnight drying at room temperature under $10^{-3}-10^{-4}$ torr before analysis, suggesting the presence of 9 weakly solvated or adsorbed water molecules 


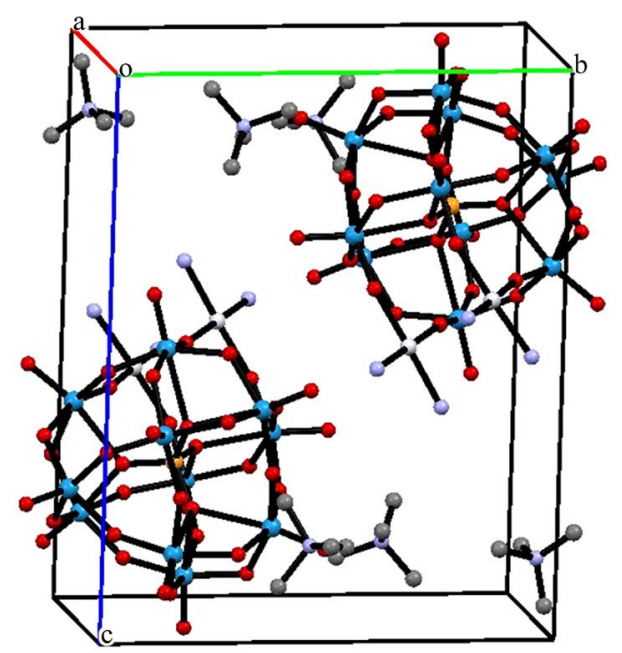

Figure S4. Solid-state packing of TMA-P-Pt.

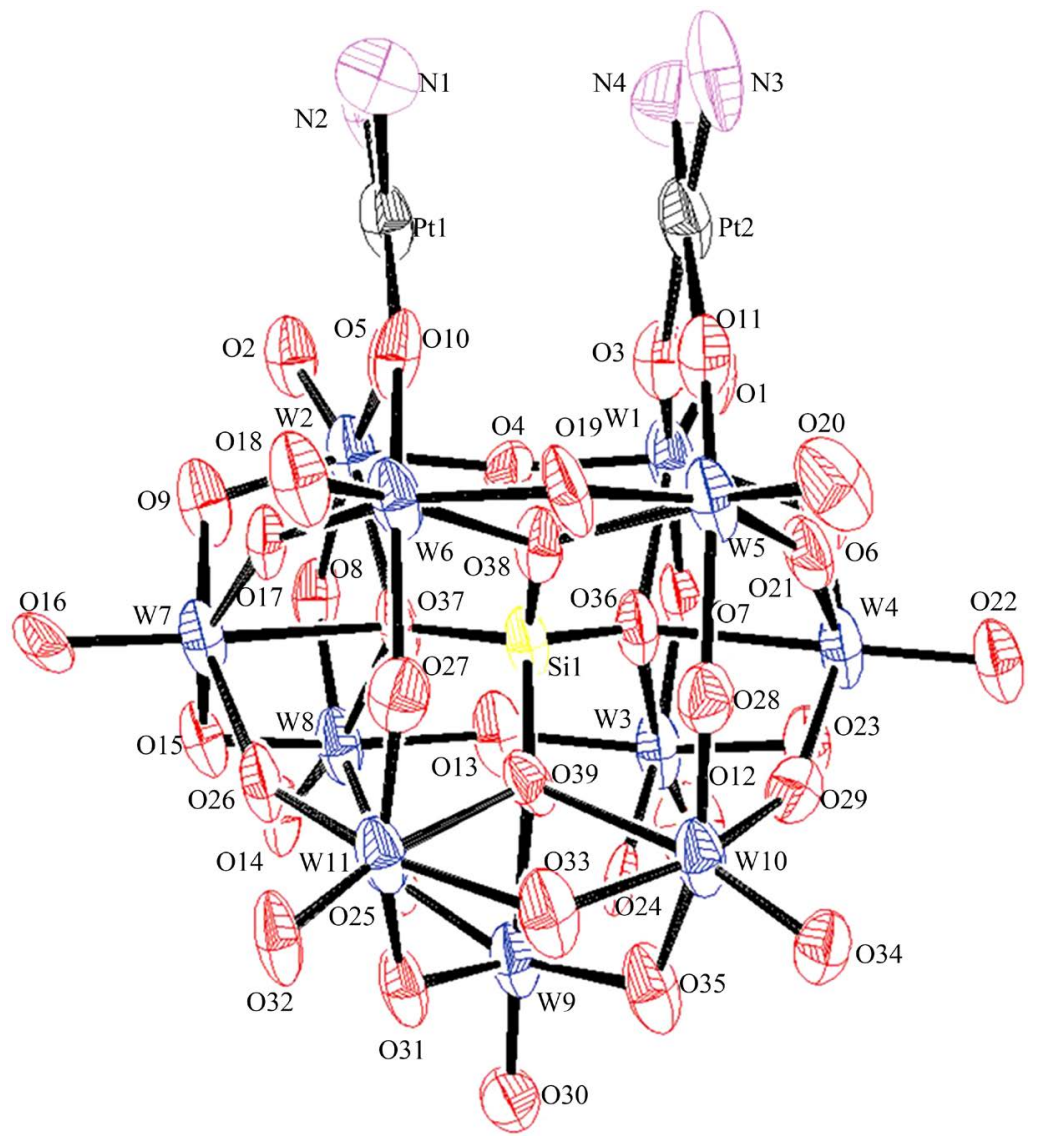

Figure S5. Molecular structure (ORTEP drawing) of TMA-Si-Pt (space group: $P 2_{1} / n$ ).

(4.43\%). TG/DTA under atmospheric conditions showed a weight loss of $6.05 \%$ without a clear endothermic point observed below $259.8^{\circ} \mathrm{C}$; calculations showed $6.39 \%$ for 13 water molecules (Figure S1). Additionally, a weight loss of $10.5 \%$ with three exothermic peaks at $268.7^{\circ} \mathrm{C}, 291.9^{\circ} \mathrm{C}$, and $401.1^{\circ} \mathrm{C}$ was observed in the temperature range 


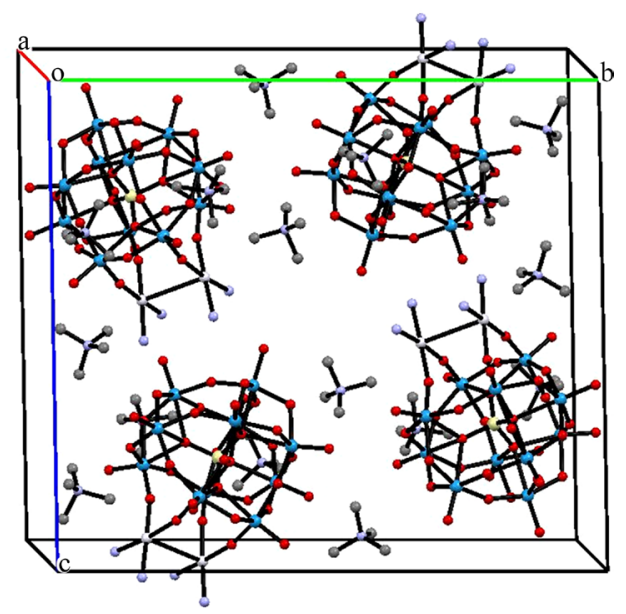

Figure S6. Solid-state packing of TMA-Si-Pt (space group: $P 2_{1} / n$ ).

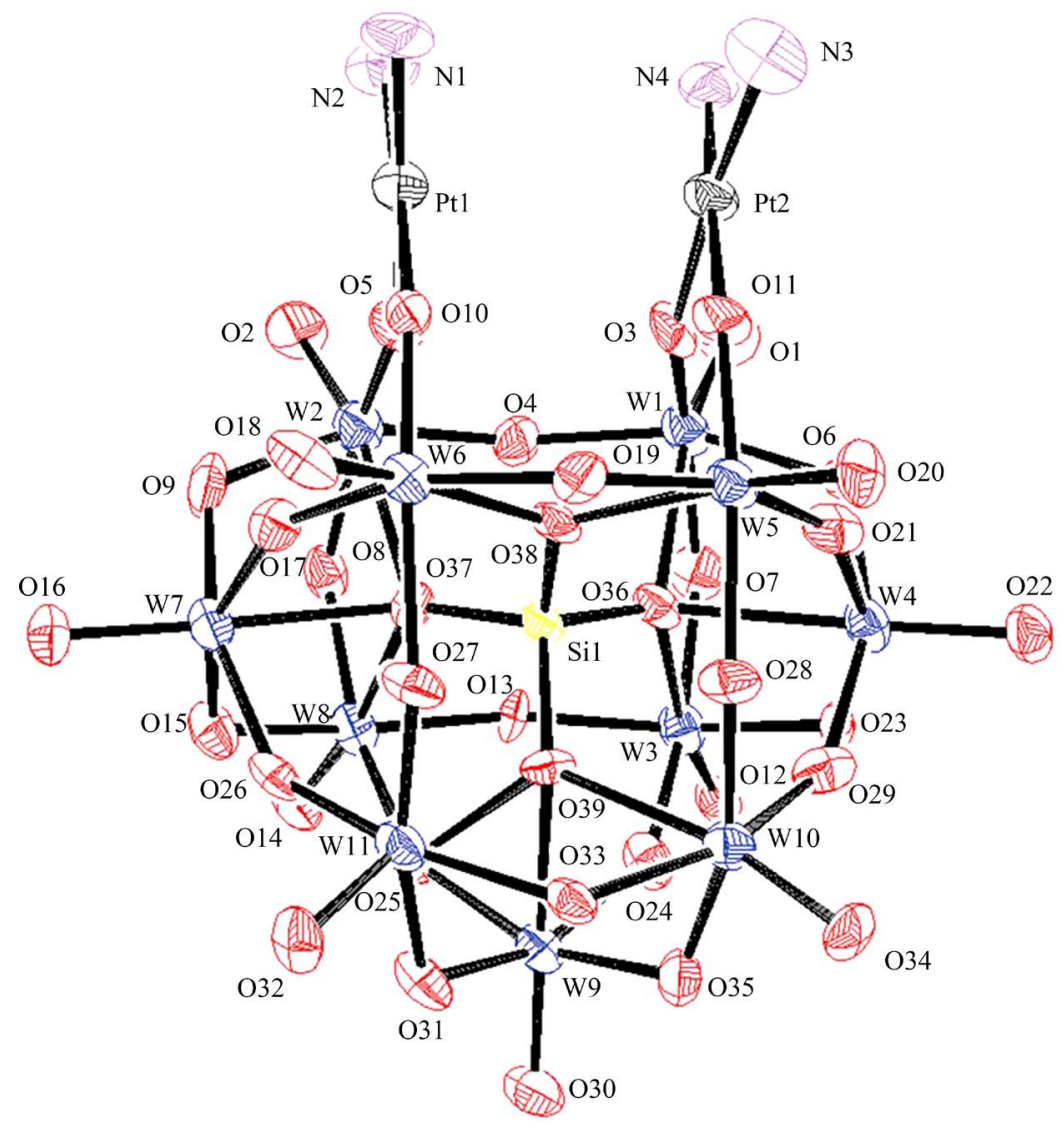

Figure S7. Molecular structure (ORTEP drawing) of TMA-Si-Pt (space group: $P 2_{1} / c$ ).

from $259.8^{\circ} \mathrm{C}$ to $420^{\circ} \mathrm{C}$; calculations showed four $\left[\left(\mathrm{CH}_{3}\right)_{4} \mathrm{~N}\right]^{+}$and four $\mathrm{NH}_{3}$ molecules (total calcd: 10.0\%). IR (KBr disk) (Figure S13) results in the $1300-400 \mathrm{~cm}^{-1}$ region (polyoxometalate region) showed: $1006 \mathrm{~m}, 950 \mathrm{~s}, 892 \mathrm{~s}, 875 \mathrm{~s}, 840 \mathrm{~s}, 790 \mathrm{~s}, 734 \mathrm{~s}, 708 \mathrm{~s}$, and $524 \mathrm{~m} \mathrm{~cm}^{-1} .{ }^{1} \mathrm{H}$ NMR (DMSO- $d_{\odot} 20.4^{\circ} \mathrm{C}$; Figure S15): 2.53 (DMSO), $3.13\left(\mathrm{CH}_{3}\right.$ ), $3.39\left(\mathrm{H}_{2} \mathrm{O}\right), 4.33\left(\mathrm{NH}_{3}\right)$, and $4.37\left(\mathrm{NH}_{3}\right)$. UV-vis absorption $\left(\right.$ in $\mathrm{H}_{2} \mathrm{O}, 7.0 \times 10^{-5} \mathrm{M}$; 


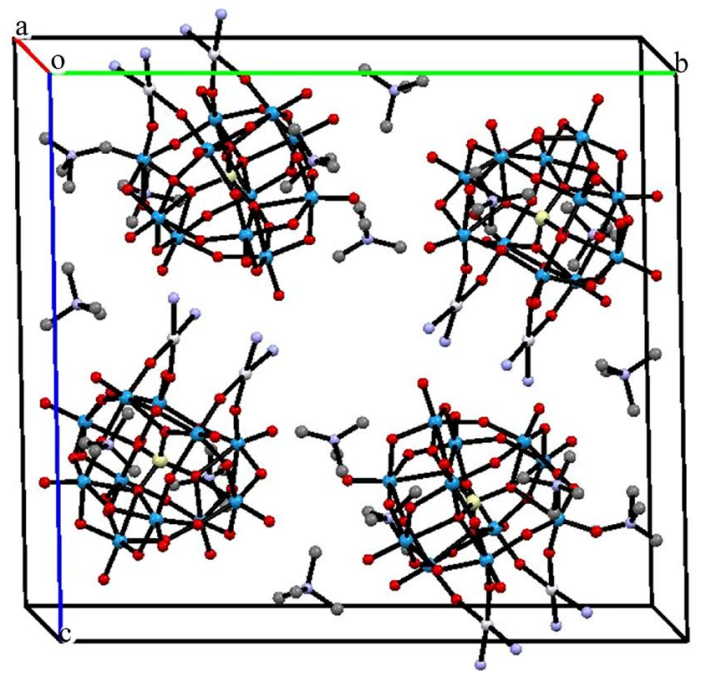

Figure S8. Solid-state packing of TMA-Si-Pt (space group: $P 2_{1} / c$ ).

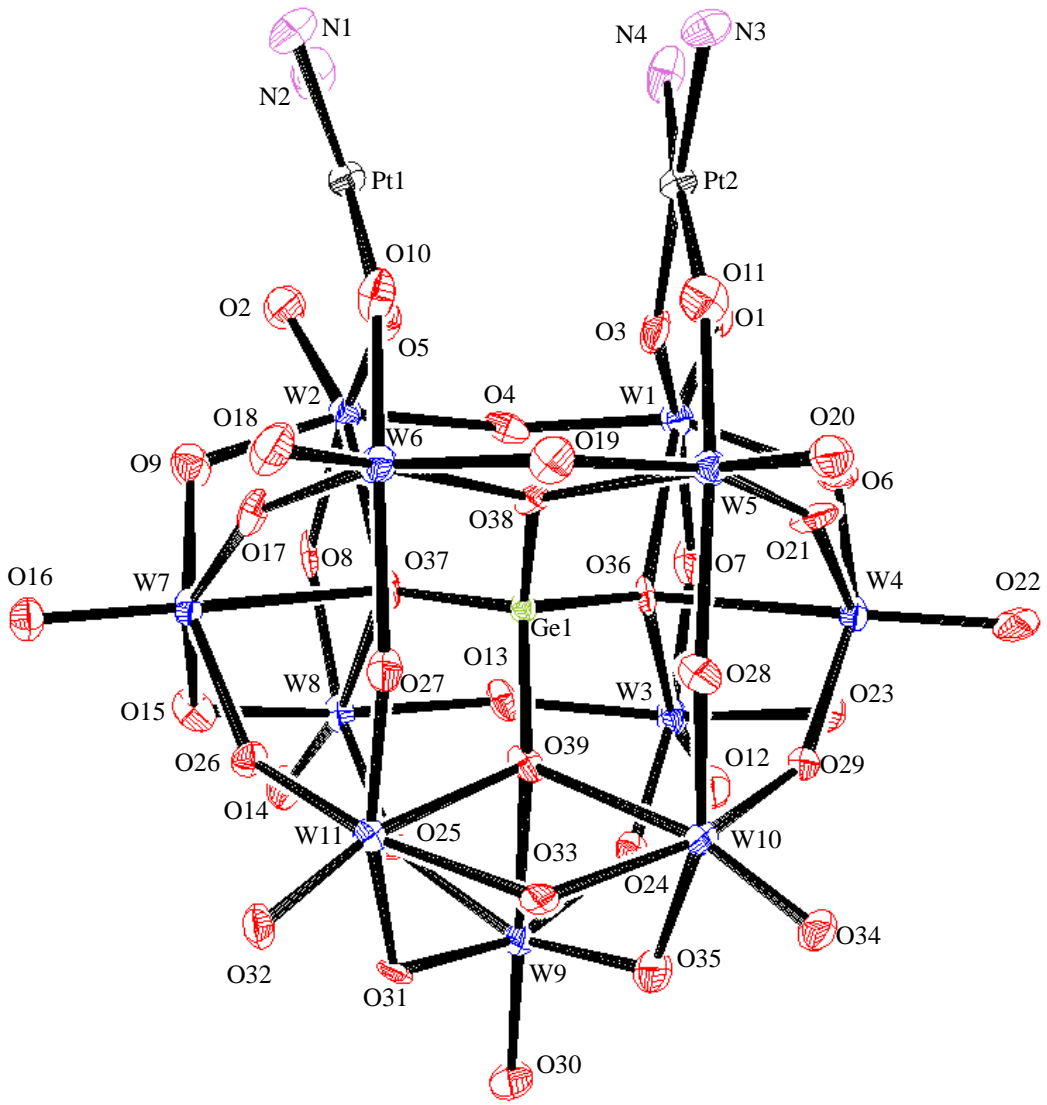

Figure S9. Molecular structure (ORTEP drawing) of TMA-Ge-Pt (space group: $P 2_{1} / n$ ).

Figure S17) showed: $\lambda 322 \mathrm{~nm}\left(\varepsilon 6775 \mathrm{M}^{-1} \mathrm{~cm}^{-1}\right)$ and $\lambda 406 \mathrm{~nm}\left(\varepsilon 1123 \mathrm{M}^{-1} \mathrm{~cm}^{-1}\right)$.

Synthesis and crystallization of $\left[\left(\mathrm{CH}_{3}\right)_{4} \mathrm{~N}\right]_{4}\left[\alpha-\mathrm{GeW}_{11} \mathrm{O}_{39}\left\{\text { cis- } \mathrm{Pt}\left(\mathrm{NH}_{3}\right)_{2}\right\}_{2}\right] \cdot 11 \mathrm{H}_{2} \mathrm{O}$ (TMA-Ge-Pt): A solution of $\mathrm{K}_{6} \mathrm{Na}_{2}\left[\mathrm{GeW}_{11} \mathrm{O}_{39}\right] \cdot 12 \mathrm{H}_{2} \mathrm{O}(0.645 \mathrm{~g} ; 0.20 \mathrm{mmol})$ dissolved in $40 \mathrm{~mL}$ of water was added to a solution of cis- $\mathrm{Pt}\left(\mathrm{NH}_{3}\right)_{2} \mathrm{Cl}_{2}(0.120 \mathrm{~g} ; 0.40 \mathrm{mmol})$ 


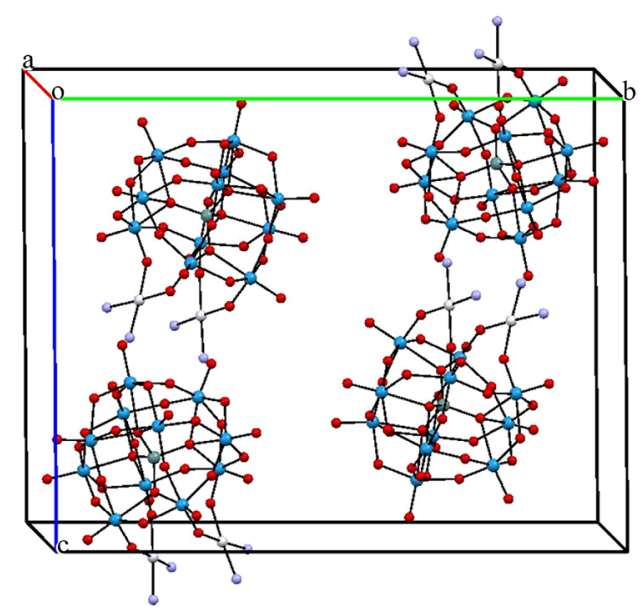

Figure S10. Solid-state packing of TMA-Ge-Pt (space group: $P 2_{1} / n$ ).

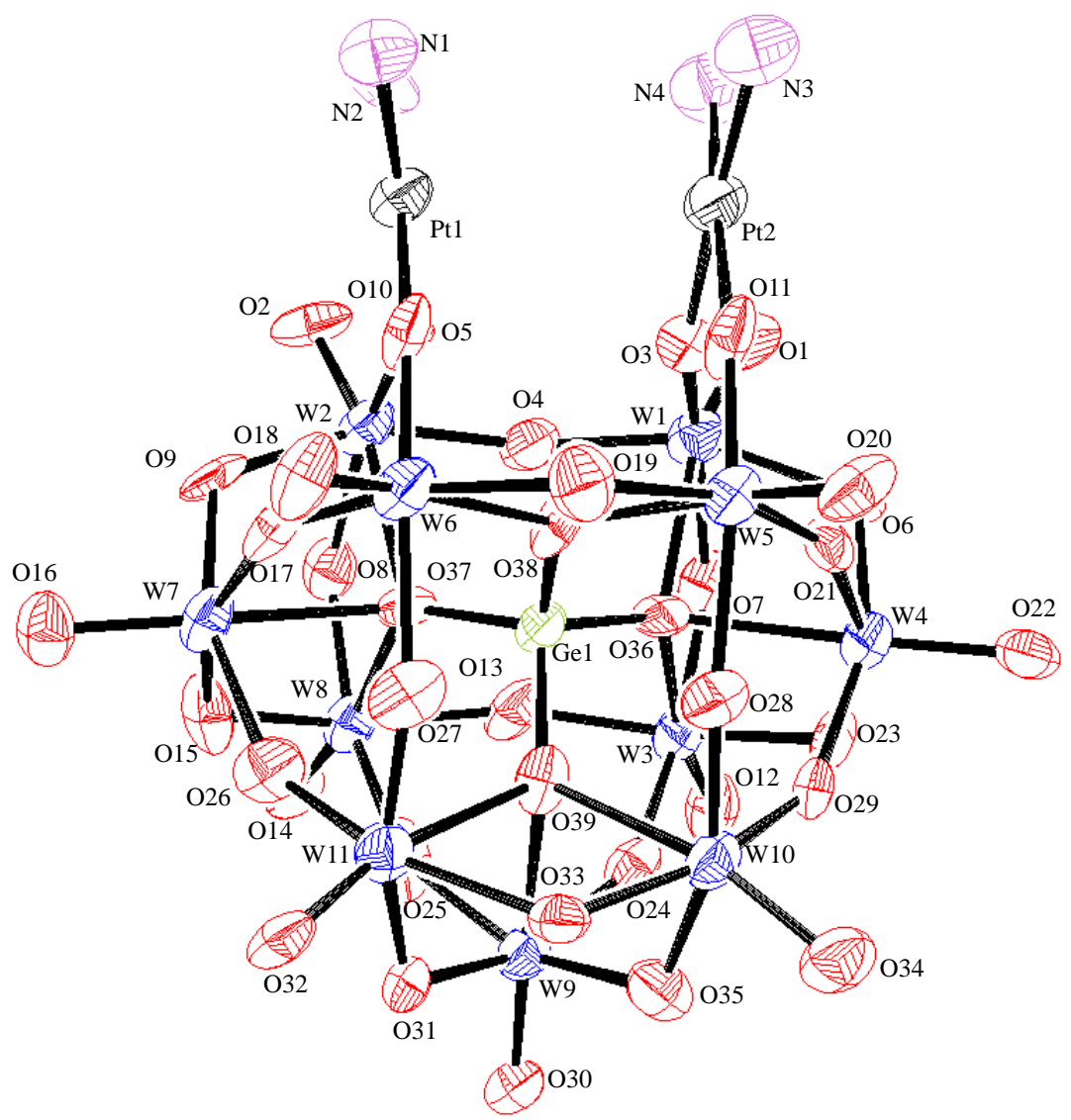

Figure S11. Molecular structure (ORTEP drawing) of TMA-Ge-Pt (space group: $P 2_{1} / c$ ).

dissolved in $150 \mathrm{~mL}$ of water at $25^{\circ} \mathrm{C}$. After stirring for 10 days at $25^{\circ} \mathrm{C}$, a yellow precipitate was formed. The yellow precipitate was removed off through a membrane filter (JG $0.2 \mu \mathrm{m})$, and solid $\left(\mathrm{CH}_{3}\right)_{4} \mathrm{NCl}(3.50 \mathrm{~g} ; 16.0 \mathrm{mmol})$ was added to the filtrate, and stirred for 3 hours in an ice bath. Then, a yellow precipitate was collected by a membrane filter (JG $0.2 \mu \mathrm{m}$ ), and washed with a small amount of ethanol. For purification, 


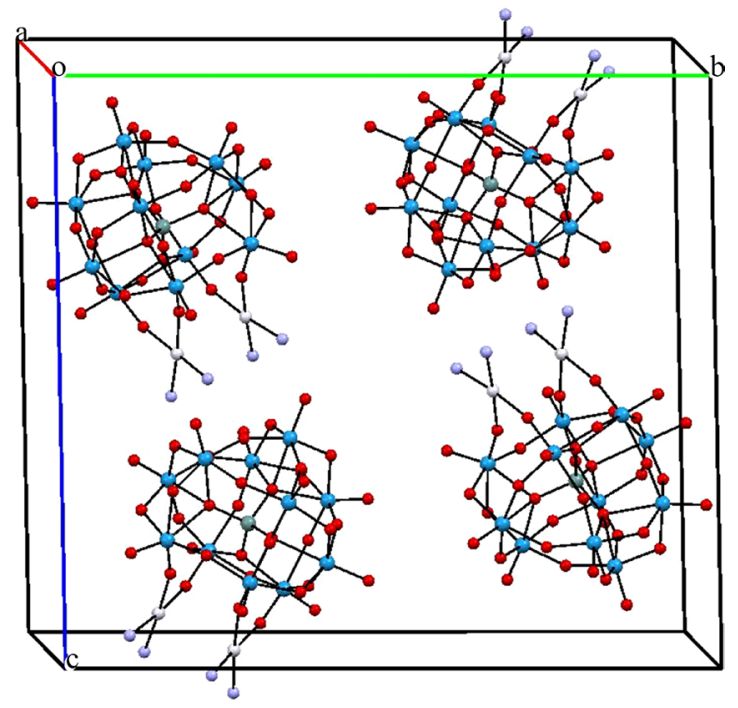

Figure S12. Solid-state packing of TMA-Ge-Pt (space group: $P 2_{1} / c$ ).

Table S1. Selected bond lengths and angles around the platinum centers of TMA-P-Pt.

\begin{tabular}{|c|c|c|c|}
\hline \multicolumn{4}{|c|}{ Lengths $(\AA)$} \\
\hline $\mathrm{Pt}(1)-\mathrm{O}(5)$ & $2.021(13)$ & $\mathrm{W}(1)-\mathrm{O}(3)$ & $1.729(13)$ \\
\hline $\mathrm{Pt}(1)-\mathrm{O}(10)$ & $1.997(11)$ & $\mathrm{W}(2)-\mathrm{O}(5)$ & $1.756(13)$ \\
\hline $\mathrm{Pt}(2)-\mathrm{O}(3)$ & $2.049(13)$ & $\mathrm{W}(5)-\mathrm{O}(11)$ & $1.793(13)$ \\
\hline $\mathrm{Pt}(2)-\mathrm{O}(11)$ & $1.999(13)$ & $\mathrm{W}(6)-\mathrm{O}(10)$ & $1.792(11)$ \\
\hline Average & 2.017 & Average & 1.768 \\
\hline $\operatorname{Pt}(1)-\mathrm{N}(1)$ & $2.030(16)$ & $\mathrm{W}(1)-\mathrm{O}(4)$ & $1.932(11)$ \\
\hline $\mathrm{Pt}(1)-\mathrm{N}(2)$ & $2.054(16)$ & $\mathrm{W}(2)-\mathrm{O}(4)$ & $1.886(12)$ \\
\hline $\operatorname{Pt}(2)-N(3)$ & $2.028(17)$ & $\mathrm{W}(5)-\mathrm{O}(19)$ & $1.924(13)$ \\
\hline $\operatorname{Pt}(2)-\mathrm{N}(4)$ & $2.057(17)$ & $\mathrm{W}(6)-\mathrm{O}(19)$ & $1.958(11)$ \\
\hline \multirow[t]{2}{*}{ Average } & 2.042 & Average & 1.925 \\
\hline & & $\operatorname{Pt}(1) \cdots \operatorname{Pt}(2)$ & 3.267 \\
\hline \multicolumn{4}{|c|}{ Angles $\left({ }^{\circ}\right)$} \\
\hline $\mathrm{Pt}(1)-\mathrm{O}(5)-\mathrm{W}(2)$ & $162.8(7)$ & $\mathrm{Pt}(2)-\mathrm{O}(3)-\mathrm{W}(1)$ & $164.0(8)$ \\
\hline $\mathrm{Pt}(1)-\mathrm{O}(10)-\mathrm{W}(6)$ & $153.4(7)$ & $\mathrm{Pt}(2)-\mathrm{O}(11)-\mathrm{W}(5)$ & $154.0(9)$ \\
\hline Average & 158.1 & Average & 159.0 \\
\hline $\mathrm{O}(5)-\mathrm{Pt}(1)-\mathrm{O}(10)$ & $91.3(5)$ & $\mathrm{O}(3)-\mathrm{Pt}(2)-\mathrm{O}(11)$ & $92.2(6)$ \\
\hline $\mathrm{O}(5)-\mathrm{Pt}(1)-\mathrm{N}(2)$ & $87.8(6)$ & $\mathrm{O}(3)-\mathrm{Pt}(2)-\mathrm{N}(4)$ & $86.7(6)$ \\
\hline $\mathrm{O}(10)-\mathrm{Pt}(1)-\mathrm{N}(1)$ & $87.0(6)$ & $\mathrm{O}(11)-\mathrm{Pt}(2)-\mathrm{N}(3)$ & $88.1(7)$ \\
\hline $\mathrm{N}(1)-\mathrm{Pt}(1)-\mathrm{N}(2)$ & $93.9(7)$ & $\mathrm{N}(3)-\mathrm{Pt}(2)-\mathrm{N}(4)$ & $93.0(7)$ \\
\hline Average & 90.0 & Average & 90.0 \\
\hline $\mathrm{W}(1)-\mathrm{O}(4)-\mathrm{W}(2)$ & $147.5(7)$ & $\mathrm{W}(5)-\mathrm{O}(19)-\mathrm{W}(6)$ & $121.6(6)$ \\
\hline
\end{tabular}


Table S2. Selected bond lengths $(\AA)$ and angles $\left({ }^{\circ}\right)$ around the platinum centers of TMA-Si-Pt (space group $P 2_{1} / n$ ).

\begin{tabular}{|c|c|c|c|}
\hline \multicolumn{4}{|c|}{ Lengths $(\AA)$} \\
\hline $\mathrm{Pt}(1)-\mathrm{O}(5)$ & $1.963(14)$ & $\mathrm{W}(1)-\mathrm{O}(3)$ & $1.760(14)$ \\
\hline $\mathrm{Pt}(1)-\mathrm{O}(10)$ & $2.060(10)$ & $\mathrm{W}(2)-\mathrm{O}(5)$ & $1.804(14)$ \\
\hline $\mathrm{Pt}(2)-\mathrm{O}(3)$ & $2.009(14)$ & $\mathrm{W}(5)-\mathrm{O}(11)$ & $1.646(11)$ \\
\hline $\mathrm{Pt}(2)-\mathrm{O}(11)$ & $2.086(11)$ & $\mathrm{W}(6)-\mathrm{O}(10)$ & $1.643(10)$ \\
\hline Average & 2.030 & Average & 1.713 \\
\hline $\operatorname{Pt}(1)-\mathrm{N}(1)$ & $2.013(18)$ & $\mathrm{W}(1)-\mathrm{O}(4)$ & $1.884(11)$ \\
\hline $\operatorname{Pt}(1)-\mathrm{N}(2)$ & $2.061(12)$ & $\mathrm{W}(2)-\mathrm{O}(4)$ & $1.925(11)$ \\
\hline $\operatorname{Pt}(2)-\mathrm{N}(3)$ & $2.030(2)$ & $\mathrm{W}(5)-\mathrm{O}(19)$ & $1.905(12)$ \\
\hline $\operatorname{Pt}(2)-\mathrm{N}(4)$ & $2.094(18)$ & $\mathrm{W}(6)-\mathrm{O}(19)$ & $1.932(11)$ \\
\hline Average & 2.050 & Average & 1.912 \\
\hline & & $\operatorname{Pt}(1) \cdots \operatorname{Pt}(2)$ & 3.237 \\
\hline \multicolumn{4}{|c|}{ Angles $\left({ }^{\circ}\right)$} \\
\hline $\mathrm{Pt}(1)-\mathrm{O}(5)-\mathrm{W}(2)$ & $160.4(6)$ & $\mathrm{Pt}(2)-\mathrm{O}(3)-\mathrm{W}(1)$ & $165.9(7)$ \\
\hline $\mathrm{Pt}(1)-\mathrm{O}(10)-\mathrm{W}(6)$ & $159.3(8)$ & $\mathrm{Pt}(2)-\mathrm{O}(11)-\mathrm{W}(5)$ & $160.0(9)$ \\
\hline Average & 159.9 & Average & 163.0 \\
\hline $\mathrm{O}(5)-\mathrm{Pt}(1)-\mathrm{O}(10)$ & $86.2(5)$ & $\mathrm{O}(3)-\mathrm{Pt}(2)-\mathrm{O}(11)$ & $86.2(5)$ \\
\hline $\mathrm{O}(5)-\mathrm{Pt}(1)-\mathrm{N}(2)$ & $87.8(6)$ & $\mathrm{O}(3)-\mathrm{Pt}(2)-\mathrm{N}(4)$ & $88.6(7)$ \\
\hline $\mathrm{O}(10)-\mathrm{Pt}(1)-\mathrm{N}(1)$ & $91.0(6)$ & $\mathrm{O}(11)-\mathrm{Pt}(2)-\mathrm{N}(3)$ & $93.8(6)$ \\
\hline $\mathrm{N}(1)-\mathrm{Pt}(1)-\mathrm{N}(2)$ & $94.8(7)$ & $\mathrm{N}(3)-\mathrm{Pt}(2)-\mathrm{N}(4)$ & $91.3(8)$ \\
\hline Average & 90.0 & Average & 90.0 \\
\hline $\mathrm{W}(1)-\mathrm{O}(4)-\mathrm{W}(2)$ & $147.4(8)$ & $\mathrm{W}(5)-\mathrm{O}(19)-\mathrm{W}(6)$ & $117.7(7)$ \\
\hline
\end{tabular}

the crude product $(0.589 \mathrm{~g})$ was dissolved in $20 \mathrm{~mL}$ of water at $70^{\circ} \mathrm{C}$, followed by standing in a refrigerator at around $5^{\circ} \mathrm{C}$. A yellow crystals was collected by a membrane filter (JG $0.2 \mu \mathrm{m}$ ). The obtained product was $0.320 \mathrm{~g}$ (the yield calculated on the basis of [mol of TMA-Ge-Pt] $/\left[\mathrm{mol}\right.$ of $\left.\mathrm{K}_{6} \mathrm{Na}_{2}\left[\mathrm{GeW}_{11} \mathrm{O}_{39}\right] \cdot 12 \mathrm{H}_{2} \mathrm{O}\right] \times 100$ was $\left.44 \%\right)$. For the X-ray crystal measurement, the crystals were obtained by vapor diffusion from water $(7.0 \mathrm{~mL}$ of water per $100 \mathrm{mg}$ of product)/ethanol at $25^{\circ} \mathrm{C}$. Elemental analysis results showed: $\mathrm{C}$, 5.25; H, 2.03; N, 3.05; Ge, 1.98; W, 57.7; Pt, 11.2\%. Calculations for

$\left[\left(\mathrm{CH}_{3}\right)_{4} \mathrm{~N}\right]_{4}\left[\mathrm{GeW}_{11} \mathrm{O}_{39}\left\{\text { cis- } \mathrm{Pt}\left(\mathrm{NH}_{3}\right)_{2}\right\}_{2}\right] \cdot \mathrm{xH}_{2} \mathrm{O}(\mathrm{x}=2)=\mathrm{C}_{16} \mathrm{H}_{64} \mathrm{~N}_{8} \mathrm{Pt}_{2} \mathrm{O}_{41} \mathrm{Ge}_{1} \mathrm{~W}_{11}: \mathrm{C}, 5.48$; $\mathrm{H}, 1.84$; N, 3.19; Ge, 2.07; W, 57.62; Pt, 11.12\%. A weight loss of $4.51 \%$ was observed during overnight drying at room temperature under $10^{-3}-10^{-4}$ torr before analysis, suggesting the presence of 9 weakly solvated or adsorbed water molecules (4.42\%). TG/DTA under atmospheric conditions showed a weight loss of $5.22 \%$ without a clear endothermic point observed below $210.8^{\circ} \mathrm{C}$; calculations showed $5.4 \%$ for 11 water molecules (Figure S2). Additionally, a weight loss of $9.89 \%$ with three exothermic 
Table S3. Selected bond lengths $(\AA)$ and angles $\left({ }^{\circ}\right)$ around the platinum centers of TMA-Si-Pt (space group $P 2_{1} / c$ ).

\begin{tabular}{|c|c|c|c|}
\hline \multicolumn{4}{|c|}{ Lengths $(\AA)$} \\
\hline $\mathrm{Pt}(1)-\mathrm{O}(5)$ & $1.978(9)$ & $\mathrm{W}(1)-\mathrm{O}(3)$ & $1.851(9)$ \\
\hline $\mathrm{Pt}(1)-\mathrm{O}(10)$ & $1.997(12)$ & $\mathrm{W}(2)-\mathrm{O}(5)$ & $1.784(9)$ \\
\hline $\mathrm{Pt}(2)-\mathrm{O}(3)$ & $1.907(9)$ & $\mathrm{W}(5)-\mathrm{O}(11)$ & $1.775(11)$ \\
\hline $\mathrm{Pt}(2)-\mathrm{O}(11)$ & $1.990(11)$ & $\mathrm{W}(6)-\mathrm{O}(10)$ & $1.780(11)$ \\
\hline Average & 1.968 & Average & 1.798 \\
\hline $\operatorname{Pt}(1)-\mathrm{N}(1)$ & $2.004(11)$ & $\mathrm{W}(1)-\mathrm{O}(4)$ & $1.920(10)$ \\
\hline $\operatorname{Pt}(1)-\mathrm{N}(2)$ & $2.032(15)$ & $\mathrm{W}(2)-\mathrm{O}(4)$ & $1.884(11)$ \\
\hline $\operatorname{Pt}(2)-N(3)$ & $1.995(11)$ & $\mathrm{W}(5)-\mathrm{O}(19)$ & $1.922(11)$ \\
\hline $\operatorname{Pt}(2)-\mathrm{N}(4)$ & $2.020(14)$ & $\mathrm{W}(6)-\mathrm{O}(19)$ & $1.922(9)$ \\
\hline Average & 2.013 & Average & 1.912 \\
\hline & & $\operatorname{Pt}(1) \cdots \operatorname{Pt}(2)$ & 3.275 \\
\hline \multicolumn{4}{|c|}{ Angles $\left({ }^{\circ}\right)$} \\
\hline $\mathrm{Pt}(1)-\mathrm{O}(5)-\mathrm{W}(2)$ & $165.3(6)$ & $\mathrm{Pt}(2)-\mathrm{O}(3)-\mathrm{W}(1)$ & $160.2(7)$ \\
\hline $\mathrm{Pt}(1)-\mathrm{O}(10)-\mathrm{W}(6)$ & $153.9(6)$ & $\mathrm{Pt}(2)-\mathrm{O}(11)-\mathrm{W}(5)$ & $151.5(5)$ \\
\hline Average & 159.6 & Average & 155.9 \\
\hline $\mathrm{O}(5)-\mathrm{Pt}(1)-\mathrm{O}(10)$ & $90.3(4)$ & $\mathrm{O}(3)-\mathrm{Pt}(2)-\mathrm{O}(11)$ & $91.6(4)$ \\
\hline $\mathrm{O}(5)-\mathrm{Pt}(1)-\mathrm{N}(2)$ & $88.0(5)$ & $\mathrm{O}(3)-\mathrm{Pt}(2)-\mathrm{N}(4)$ & $86.8(5)$ \\
\hline $\mathrm{O}(10)-\mathrm{Pt}(1)-\mathrm{N}(1)$ & $89.4(5)$ & $\mathrm{O}(11)-\mathrm{Pt}(2)-\mathrm{N}(3)$ & $86.6(5)$ \\
\hline $\mathrm{N}(1)-\operatorname{Pt}(1)-\mathrm{N}(2)$ & $92.2(5)$ & $\mathrm{N}(3)-\mathrm{Pt}(2)-\mathrm{N}(4)$ & $94.8(5)$ \\
\hline Average & 90.0 & Average & 90.0 \\
\hline $\mathrm{W}(1)-\mathrm{O}(4)-\mathrm{W}(2)$ & $147.7(6)$ & $\mathrm{W}(5)-\mathrm{O}(19)-\mathrm{W}(6)$ & $117.8(5)$ \\
\hline
\end{tabular}

peaks at $268.8,285.0$, and $315.9^{\circ} \mathrm{C}$ was observed in the temperature range from 210.8 to 403.4 ${ }^{\circ} \mathrm{C}$; calculations showed four $\left[\left(\mathrm{CH}_{3}\right)_{4} \mathrm{~N}\right]^{+}$and four $\mathrm{NH}_{3}$ molecules (total calcd: 9.9\%). IR (KBr disk) (Figure S14) results in the $1300-400 \mathrm{~cm}^{-1}$ region (polyoxometalate region) showed: 958 s, 950 s, 876 s, 839 s, 816 s, 790 s, 768 s, 717 s, 697 s, and $526 \mathrm{~m}$ $\mathrm{cm}^{-1} .{ }^{1} \mathrm{H}$ NMR (DMSO- $d_{6}, 21.9^{\circ} \mathrm{C}$; Figure S16): 2.53 (DMSO), $3.17\left(\mathrm{CH}_{3}\right), 3.36\left(\mathrm{H}_{2} \mathrm{O}\right)$, and $4.37\left(\mathrm{NH}_{3}\right) . \mathrm{UV}$-vis absorption (in $\mathrm{H}_{2} \mathrm{O}, 7.1 \times 10^{-5} \mathrm{M}$; Figure S18) showed: $\lambda 323$ $\mathrm{nm}\left(\varepsilon 7204 \mathrm{M}^{-1} \mathrm{~cm}^{-1}\right)$ and $\lambda 409 \mathrm{~nm}\left(\varepsilon 1087 \mathrm{M}^{-1} \mathrm{~cm}^{-1}\right)$.

Crystallization of $\left[\left(\mathrm{CH}_{3}\right)_{4} \mathrm{~N}\right]_{3}\left[\mathrm{PW}_{11} \mathrm{O}_{39}\left\{\text { cis- } \mathrm{Pt}\left(\mathrm{NH}_{3}\right)_{2}\right\}_{2}\right] \cdot 10 \mathrm{H}_{2} \mathrm{O}$ (TMA-P-Pt): A powder sample of TMA-P-Pt $(69.3 \mathrm{mg})$ was dissolved in $23 \mathrm{~mL}$ of water at $25^{\circ} \mathrm{C}$. The crystallization was performed by vapor diffusion from acetone at $25^{\circ} \mathrm{C}$ for a week. The characterization results obtained by TG/DTA, ${ }^{1} \mathrm{H}$ and ${ }^{31} \mathrm{P}$ NMR, and FT-IR spectroscopy were completely identical with those of the powder sample.

Crystal data for $\left[\left(\mathrm{CH}_{3}\right)_{4} \mathrm{~N}\right]_{3}\left[\mathrm{PW}_{11} \mathrm{O}_{39}\left\{\text { cis- } \mathrm{Pt}\left(\mathrm{NH}_{3}\right)_{2}\right\}_{2}\right] \cdot 10 \mathrm{H}_{2} \mathrm{O}$ (TMA-P-Pt): $\mathrm{C}_{12} \mathrm{H}_{68} \mathrm{~N}_{7} \mathrm{Pt}_{2} \mathrm{O}_{49} \mathrm{P}_{1} \mathrm{~W}_{11} ; \mathrm{M}=3538.19$, triclinic, space group: $P$-1 (\#2), $a=13.232(3) \AA, b=$ 
Table S4. Selected bond lengths $(\AA)$ and angles $\left(^{\circ}\right)$ around the platinum centers of TMA-Ge-Pt (space group $P 2_{1} / n$ ).

\begin{tabular}{|c|c|c|c|}
\hline \multicolumn{4}{|c|}{ Lengths $(\AA)$} \\
\hline $\mathrm{Pt}(1)-\mathrm{O}(5)$ & $1.986(11)$ & $\mathrm{W}(1)-\mathrm{O}(3)$ & $1.787(12)$ \\
\hline $\mathrm{Pt}(1)-\mathrm{O}(10)$ & $2.013(10)$ & $\mathrm{W}(2)-\mathrm{O}(5)$ & $1.790(11)$ \\
\hline $\mathrm{Pt}(2)-\mathrm{O}(3)$ & $1.986(11)$ & $\mathrm{W}(5)-\mathrm{O}(11)$ & $1.780(10)$ \\
\hline $\mathrm{Pt}(2)-\mathrm{O}(11)$ & $2.005(11)$ & $\mathrm{W}(6)-\mathrm{O}(10)$ & $1.774(10)$ \\
\hline Average & 1.998 & Average & 1.783 \\
\hline $\operatorname{Pt}(1)-\mathrm{N}(1)$ & $2.023(16)$ & $\mathrm{W}(1)-\mathrm{O}(4)$ & $1.937(10)$ \\
\hline $\mathrm{Pt}(1)-\mathrm{N}(2)$ & $2.018(13)$ & $\mathrm{W}(2)-\mathrm{O}(4)$ & $1.895(10)$ \\
\hline $\mathrm{Pt}(2)-\mathrm{N}(3)$ & $2.013(13)$ & $\mathrm{W}(5)-\mathrm{O}(19)$ & $1.957(10)$ \\
\hline $\mathrm{Pt}(2)-\mathrm{N}(4)$ & $2.049(13)$ & $\mathrm{W}(6)-\mathrm{O}(19)$ & $1.949(10)$ \\
\hline \multirow[t]{2}{*}{ Average } & 2.026 & Average & 1.935 \\
\hline & & $\operatorname{Pt}(1) \cdots \operatorname{Pt}(2)$ & 3.455 \\
\hline \multicolumn{4}{|c|}{ Angles $\left({ }^{\circ}\right)$} \\
\hline $\mathrm{Pt}(1)-\mathrm{O}(5)-\mathrm{W}(2)$ & $151.5(6)$ & $\mathrm{Pt}(2)-\mathrm{O}(3)-\mathrm{W}(1)$ & $157.0(6)$ \\
\hline $\mathrm{Pt}(1)-\mathrm{O}(10)-\mathrm{W}(6)$ & $146.9(7)$ & $\mathrm{Pt}(2)-\mathrm{O}(11)-\mathrm{W}(5)$ & $146.6(7)$ \\
\hline Average & 149.2 & Average & 151.8 \\
\hline $\mathrm{O}(5)-\mathrm{Pt}(1)-\mathrm{O}(10)$ & $91.5(4)$ & $\mathrm{O}(3)-\mathrm{Pt}(2)-\mathrm{O}(11)$ & $92.5(4)$ \\
\hline $\mathrm{O}(5)-\mathrm{Pt}(1)-\mathrm{N}(2)$ & $87.3(5)$ & $\mathrm{O}(3)-\mathrm{Pt}(2)-\mathrm{N}(4)$ & $87.3(5)$ \\
\hline $\mathrm{O}(10)-\mathrm{Pt}(1)-\mathrm{N}(1)$ & $87.8(5)$ & $\mathrm{O}(11)-\mathrm{Pt}(2)-\mathrm{N}(3)$ & $86.4(5)$ \\
\hline $\mathrm{N}(1)-\operatorname{Pt}(1)-\mathrm{N}(2)$ & $93.3(6)$ & $\mathrm{N}(3)-\operatorname{Pt}(2)-\mathrm{N}(4)$ & $93.8(5)$ \\
\hline Average & 90.0 & Average & 90.0 \\
\hline $\mathrm{W}(1)-\mathrm{O}(4)-\mathrm{W}(2)$ & $146.2(6)$ & $W(5)-O(19)-W(6)$ & $116.1(5)$ \\
\hline
\end{tabular}

13.720(3) $\AA, c=17.362(3) \AA, \alpha=89.776(4), \beta=82.439(5)^{\circ}, \gamma=84.986(5), V=3112.5(11)$ $\AA^{3}, Z=2, D_{\mathrm{c}}=3.775 \mathrm{~g} / \mathrm{cm}^{3}, \mu(\mathrm{MoK} \alpha)=248.425 \mathrm{~cm}^{-1}, R_{1}=0.0742[I>2 \sigma(D)], w R_{2}=$ 0.2076 (for all data). GOF $=0.996$ [29787 total reflections and 13856 unique reflections where $I>2 \sigma(I)$ ]. CCDC No. 1472522. The molecular structure and unit cell packings of TMA-P-Pt are shown in Figure S3 and Figure S4.

Crystal data for $\left[\left(\mathrm{CH}_{3}\right)_{4} \mathrm{~N}\right]_{4}\left[\mathrm{SiW}_{11} \mathrm{O}_{39}\left\{\text { cis- } \mathrm{Pt}\left(\mathrm{NH}_{3}\right)_{2}\right\}_{2}\right] \cdot 13 \mathrm{H}_{2} \mathrm{O}$ (TMA-Si-Pt) (space group $\left.P 2_{1} / n\right): \mathrm{C}_{16} \mathrm{H}_{86} \mathrm{~N}_{8} \mathrm{Pt}_{2} \mathrm{O}_{52} \mathrm{Si}_{1} \mathrm{~W}_{11} ; \mathrm{M}=3663.49$, monoclinic, space group: $P 2_{1} / n$ (\#14), $a=$ 13.4189(16) $\AA, b=24.808(3) \AA, c=22.351(3) \AA, \beta=105,820(3)^{\circ}, V=7158.7(16) \AA^{3}, Z$ $=4, D_{\mathrm{c}}=3.399 \mathrm{~g} / \mathrm{cm}^{3}, \mu(\mathrm{MoK} \alpha)=216.063 \mathrm{~cm}^{-1}, R_{1}=0.0620[I>2 \sigma(I)], w R_{2}=0.1822$ (for all data). GOF $=0.901$ [68797 total reflections and 16430 unique reflections where $I>2 \sigma(I)$ ]. CCDC No. 1472524. The molecular structure and unit cell packings of TMA-Si-Pt (space group $P 2_{1} / n$ ) are shown in Figure $\mathrm{S} 5$ and Figure $\mathrm{S} 6$.

Crystal data for $\left[\left(\mathrm{CH}_{3}\right)_{4} \mathrm{~N}\right]_{4}\left[\mathrm{SiW}_{11} \mathrm{O}_{39}\left\{\text { cis- } \mathrm{Pt}\left(\mathrm{NH}_{3}\right)_{2}\right\}_{2}\right] \cdot 13 \mathrm{H}_{2} \mathrm{O}$ (TMA-Si-Pt) (space group $\left.P 2_{1} / c\right): \mathrm{C}_{16} \mathrm{H}_{86} \mathrm{~N}_{8} \mathrm{Pt}_{2} \mathrm{O}_{52} \mathrm{Si}_{1} \mathrm{~W}_{11} ; \mathrm{M}=3663.49$, monoclinic, space group: $P 2_{1} / c$ (\#14), a = 
Table S5. Selected bond lengths $(\AA)$ and angles $\left(^{\circ}\right)$ around the platinum centers of TMA-Ge-Pt (space group $P 2_{1} / c$ ).

\begin{tabular}{|c|c|c|c|}
\hline \multicolumn{4}{|c|}{ Lengths $(\AA)$} \\
\hline $\mathrm{Pt}(1)-\mathrm{O}(5)$ & $2.023(13)$ & $\mathrm{W}(1)-\mathrm{O}(3)$ & $1.743(17)$ \\
\hline $\mathrm{Pt}(1)-\mathrm{O}(10)$ & $2.040(2)$ & $\mathrm{W}(2)-\mathrm{O}(5)$ & $1.746(14)$ \\
\hline $\mathrm{Pt}(2)-\mathrm{O}(3)$ & $2.030(17)$ & $\mathrm{W}(5)-\mathrm{O}(11)$ & $1.700(2)$ \\
\hline $\mathrm{Pt}(2)-\mathrm{O}(11)$ & $2.060(2)$ & $\mathrm{W}(6)-\mathrm{O}(10)$ & $1.680(2)$ \\
\hline Average & 2.038 & Average & 1.717 \\
\hline $\operatorname{Pt}(1)-N(1)$ & $2.000(2)$ & $\mathrm{W}(1)-\mathrm{O}(4)$ & $1.900(2)$ \\
\hline $\operatorname{Pt}(1)-\mathrm{N}(2)$ & $2.040(3)$ & $\mathrm{W}(2)-\mathrm{O}(4)$ & $1.950(19)$ \\
\hline $\operatorname{Pt}(2)-N(3)$ & $2.030(2)$ & $\mathrm{W}(5)-\mathrm{O}(19)$ & $1.923(19)$ \\
\hline $\operatorname{Pt}(2)-N(4)$ & $2.040(3)$ & $\mathrm{W}(6)-\mathrm{O}(19)$ & $1.950(2)$ \\
\hline \multirow[t]{2}{*}{ Average } & 2.028 & Average & 1.931 \\
\hline & & $\operatorname{Pt}(1) \cdots \operatorname{Pt}(2)$ & 3.300 \\
\hline \multicolumn{4}{|c|}{ Angles $\left({ }^{\circ}\right)$} \\
\hline $\mathrm{Pt}(1)-\mathrm{O}(5)-\mathrm{W}(2)$ & $160.7(10)$ & $\mathrm{Pt}(2)-\mathrm{O}(3)-\mathrm{W}(1)$ & $163.3(11)$ \\
\hline $\mathrm{Pt}(1)-\mathrm{O}(10)-\mathrm{W}(6)$ & $155.4(10)$ & $\mathrm{Pt}(2)-\mathrm{O}(11)-\mathrm{W}(5)$ & $154.2(11)$ \\
\hline Average & 158.1 & Average & 158.8 \\
\hline $\mathrm{O}(5)-\mathrm{Pt}(1)-\mathrm{O}(10)$ & $90.2(7)$ & $\mathrm{O}(3)-\mathrm{Pt}(2)-\mathrm{O}(11)$ & $89.1(8)$ \\
\hline $\mathrm{O}(5)-\mathrm{Pt}(1)-\mathrm{N}(2)$ & $85.6(8)$ & $\mathrm{O}(3)-\mathrm{Pt}(2)-\mathrm{N}(4)$ & $87.1(10)$ \\
\hline $\mathrm{O}(10)-\mathrm{Pt}(1)-\mathrm{N}(1)$ & $88.7(9)$ & $\mathrm{O}(11)-\mathrm{Pt}(2)-\mathrm{N}(3)$ & $91.7(10)$ \\
\hline $\mathrm{N}(1)-\mathrm{Pt}(1)-\mathrm{N}(2)$ & $95.2(10)$ & $\mathrm{N}(3)-\mathrm{Pt}(2)-\mathrm{N}(4)$ & $91.9(11)$ \\
\hline Average & 89.9 & Average & 90.0 \\
\hline $\mathrm{W}(1)-\mathrm{O}(4)-\mathrm{W}(2)$ & $146.3(10)$ & $\mathrm{W}(5)-\mathrm{O}(19)-\mathrm{W}(6)$ & $117.0(9)$ \\
\hline
\end{tabular}

(a)
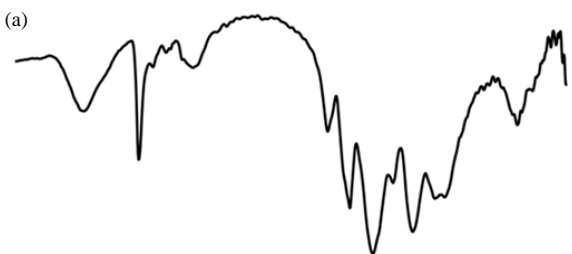

(b)
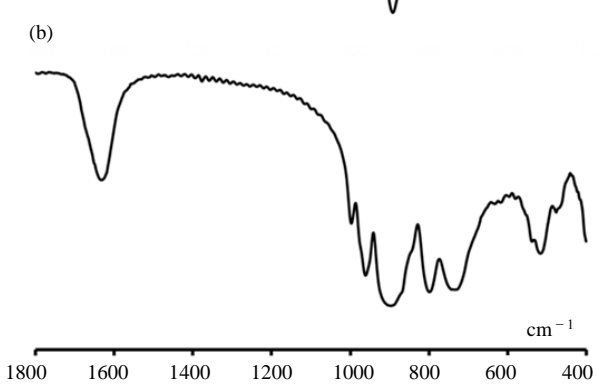

Figure S13. FTIR spectra in the polyoxoanion region $\left(1800-400 \mathrm{~cm}^{-1}\right)$, measured as $\mathrm{KBr}$ disks, of (a) TMA-Si-Pt and (b) $\mathrm{K}_{8}\left[\mathrm{SiW}_{11} \mathrm{O}_{39}\right] \cdot 17 \mathrm{H}_{2} \mathrm{O}$. 

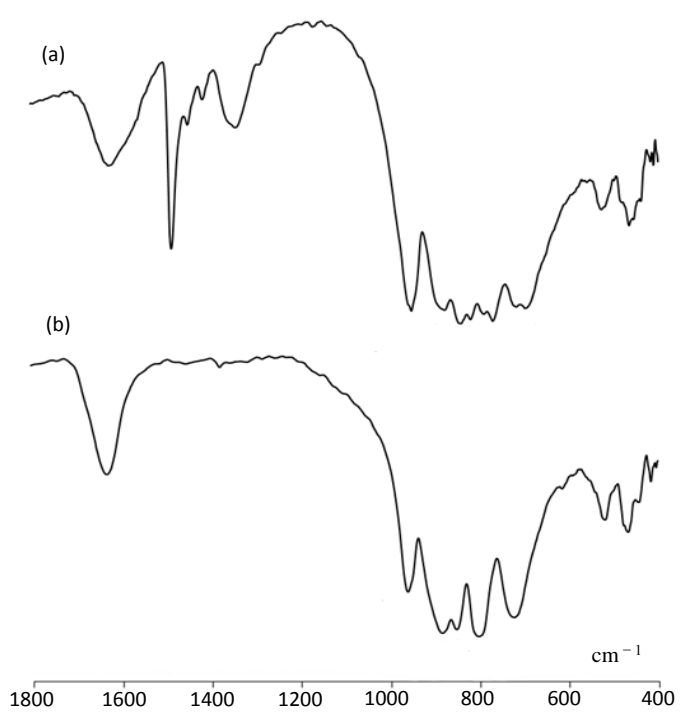

Figure S14. FTIR spectra in the polyoxoanion region $\left(1800-400 \mathrm{~cm}^{-1}\right)$, measured as $\mathrm{KBr}$ disks, of (a) TMA-Ge-Pt and (b) $\mathrm{K}_{6} \mathrm{Na}_{2}\left[\mathrm{GeW}_{11} \mathrm{O}_{39}\right] \cdot 12 \mathrm{H}_{2} \mathrm{O}$.

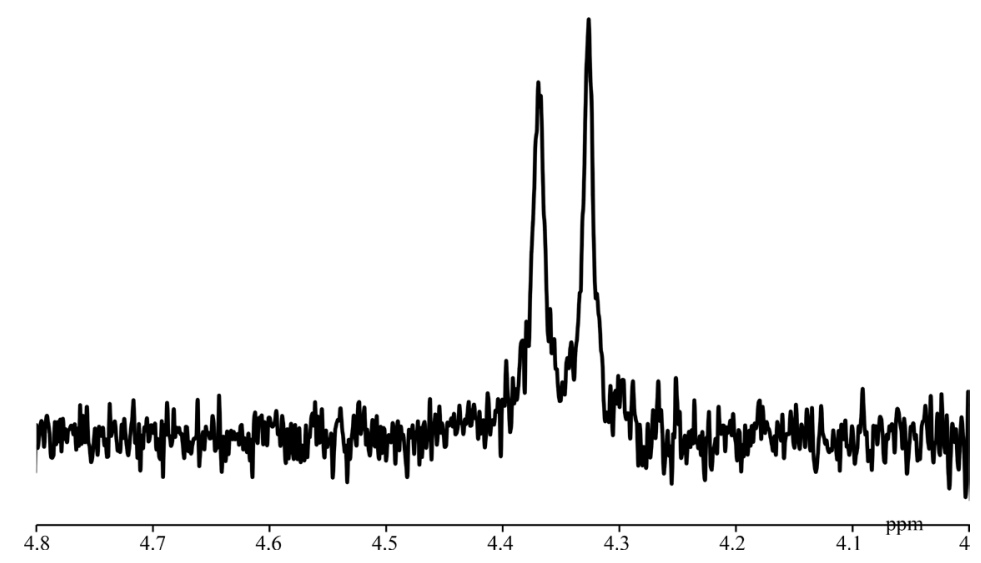

Figure S15. ${ }^{1} \mathrm{H}$ NMR spectrum in DMSO- $d_{6}$ of TMA-Si-Pt. The spectrum was referenced to an internal standard of DSS.

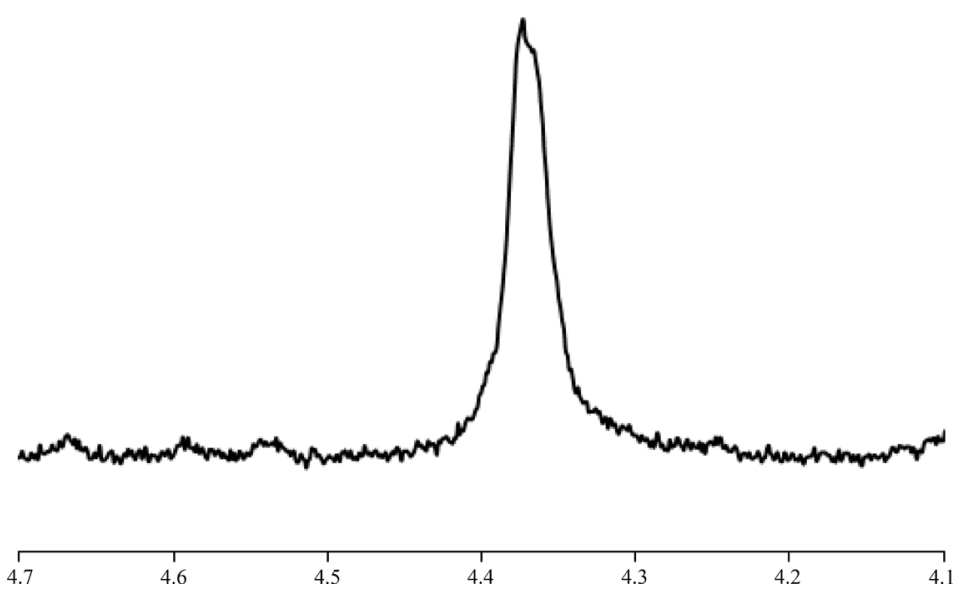

Figure S16. ${ }^{1} \mathrm{H}$ NMR spectrum in DMSO- $d_{6}$ of TMA-Ge-Pt. The spectrum was referenced to an internal standard of DSS. 


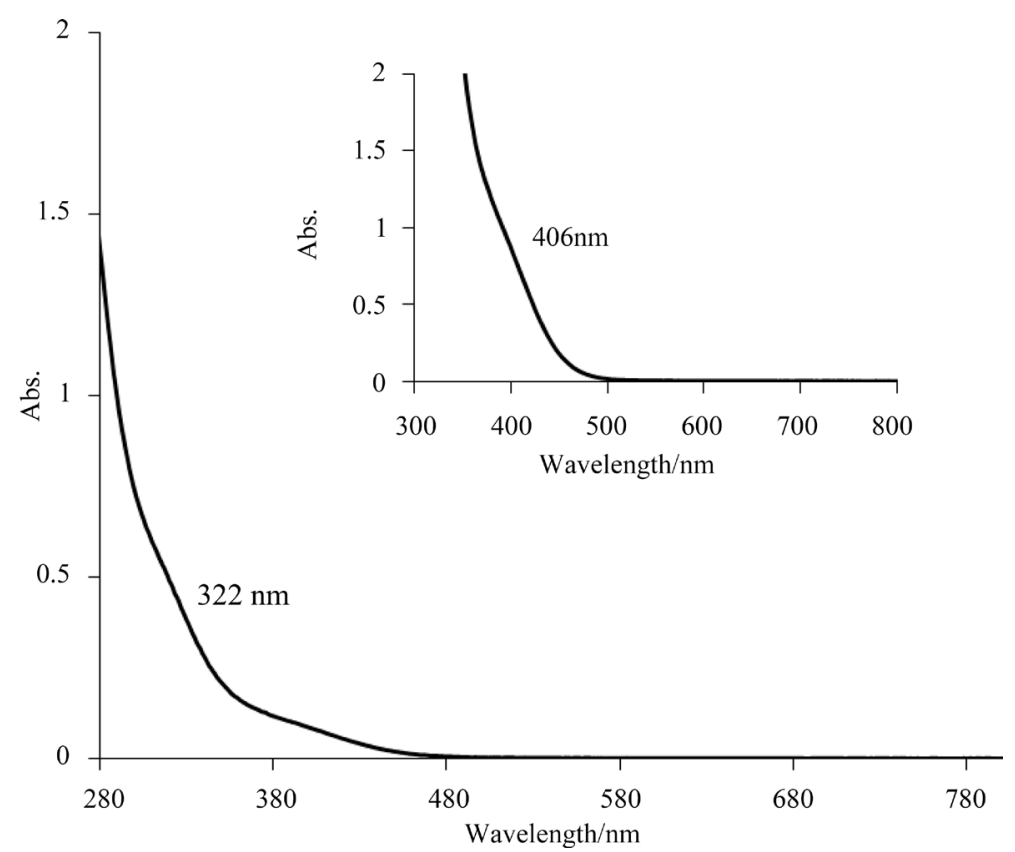

Figure S17. UV-Vis spectrum of TMA-Si-Pt in $\mathrm{H}_{2} \mathrm{O}$ in the range of $280-800 \mathrm{~nm}\left(7.23 \times 10^{-5}\right.$ $\mathrm{M})$. Inset: in the range of $300-800 \mathrm{~nm}$.

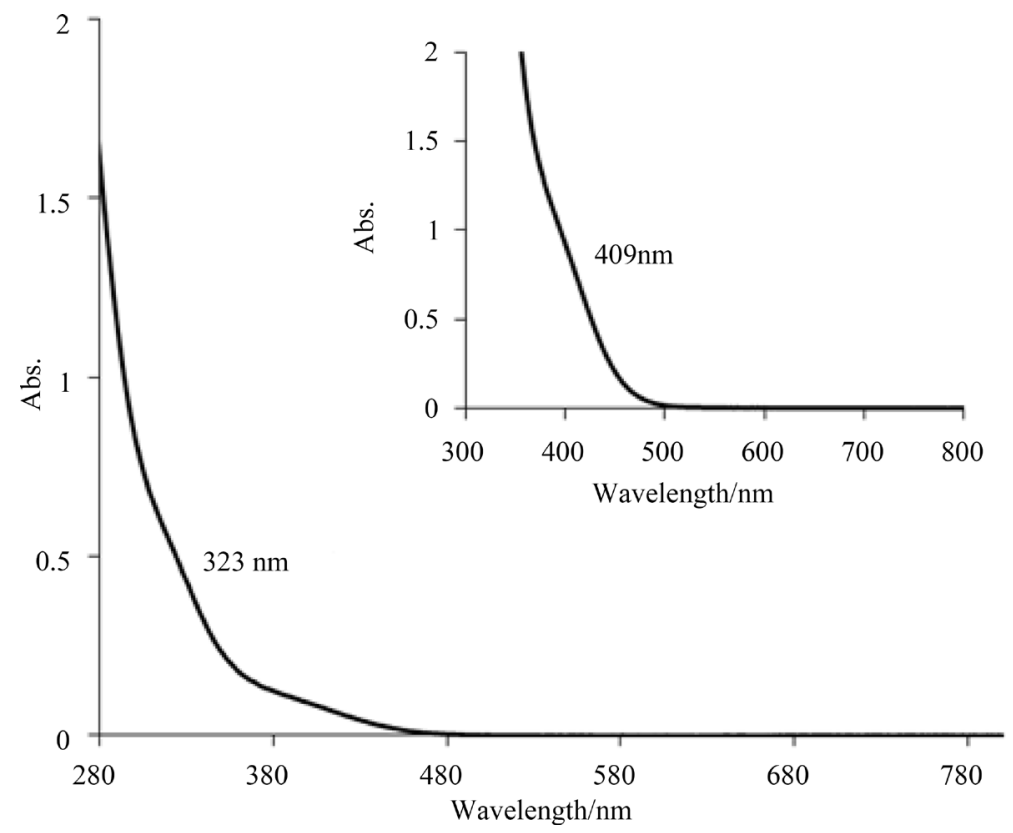

Figure S18. UV-Vis spectrum of TMA-Ge-Pt in $\mathrm{H}_{2} \mathrm{O}$ in the range of $280-800 \mathrm{~nm}\left(7.23 \times 10^{-5}\right.$ $\mathrm{M})$. Inset: in the range of $300-800 \mathrm{~nm}$.

13.4261(10) $\mathrm{\AA}, b=24.8114(17) \AA, c=22.8205(15) \AA, \beta=106.679(4)^{\circ}, V=7282.1(9) \AA^{3}$, $Z=4, D_{\mathrm{c}}=3.341 \mathrm{~g} / \mathrm{cm}^{3}, \mu($ Mo K $\alpha)=212.402 \mathrm{~cm}^{-1}, R_{1}=0.0542[I>2 \sigma(I)], w R_{2}=$ 0.0979 (for all data). GOF $=0.921$ [68063 total reflections and 16679 unique reflections where $I>2 \sigma(I)]$. CCDC No. 1472523. The molecular structure and unit cell packings of TMA-Si-Pt (space group $P 2_{1} / c$ ) are shown in Figure S7 and Figure S8. 


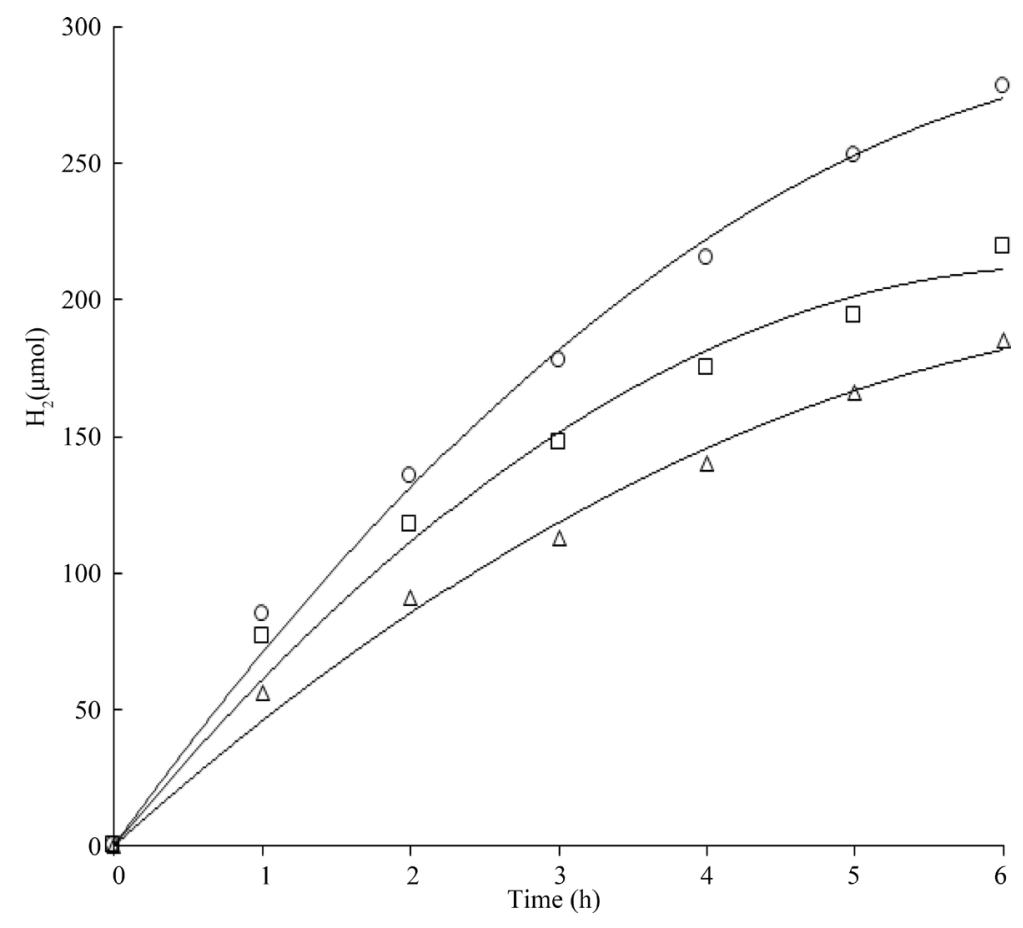

Figure S19. Time course for hydrogen evolution from aqueous TEA solution under visible light irradiation. Reaction conditions: TMA-P-Pt $(\bigcirc)$, TMA-Si-Pt $(\triangle)$, and TMA-Ge-Pt $(\square)(1.0$ $\mu \mathrm{mol}$ of Pt), EY $(2.5 \mu \mathrm{mol}), \mathrm{K}-\mathrm{Si}-\mathrm{Al}(2.5 \mu \mathrm{mol}), \mathrm{TiO}_{2}$ (anatase : rutile $\left.=80: 20\right) 50 \mathrm{mg}, 100 \mathrm{mM}$ TEA aqueous solution ( $10 \mathrm{~mL}, \mathrm{pH} 7$ ), light irradiation at $\geq 400 \mathrm{~nm}$ at $25^{\circ} \mathrm{C}$.

Crystal data for $\left[\left(\mathrm{CH}_{3}\right)_{4} \mathrm{~N}\right]_{4}\left[\alpha-\mathrm{GeW}_{11} \mathrm{O}_{39}\left\{\text { cis- } \mathrm{Pt}\left(\mathrm{NH}_{3}\right)_{2}\right\}_{2}\right] \cdot 11 \mathrm{H}_{2} \mathrm{O}$ (TMA-Ge-Pt) (space group $\left.P 2_{1} / n\right): \mathrm{C}_{16} \mathrm{H}_{82} \mathrm{~N}_{8} \mathrm{Pt}_{2} \mathrm{O}_{50} \mathrm{Ge}_{1} \mathrm{~W}_{11} ; \mathrm{M}=3671.97$, monoclinic, space group: $P 2_{1} / n$ (\#14), $a=12.917(2) \AA, b=25.826(4) \AA, c=20.431(2) \AA, \beta=100.515(3)^{\circ}, V=6701.1$ (18) $\AA^{3}, Z=4, D_{\mathrm{c}}=3.639 \mathrm{~g} / \mathrm{cm}^{3}, \mu(\mathrm{Mo} \mathrm{K} \alpha)=234.995 \mathrm{~cm}^{-1}, R_{1}=0.0605[I>2 \sigma(I)]$, $w R_{2}=0.1353$ (for all data). GOF $=1.162$ [109879 total reflections and 15397 unique reflections where $I>2 \sigma(I)]$. CCDC No. 1472526. The molecular structure and unit cell packings of TMA-Ge-Pt (space group $P 2_{1} / n$ ) are shown in Figure $\mathrm{S} 9$ and Figure $\mathrm{S} 10$.

Crystal data for $\left[\left(\mathrm{CH}_{3}\right)_{4} \mathrm{~N}\right]_{4}\left[\alpha-\mathrm{GeW}_{11} \mathrm{O}_{39}\left\{c i s-\mathrm{Pt}\left(\mathrm{NH}_{3}\right)_{2}\right\}_{2}\right] \cdot 11 \mathrm{H}_{2} \mathrm{O}$ (TMA-Ge-Pt) (space group $\left.P 2_{1} / c\right): \mathrm{C}_{16} \mathrm{H}_{82} \mathrm{~N}_{8} \mathrm{Pt}_{2} \mathrm{O}_{50} \mathrm{Ge}_{1} \mathrm{~W}_{11} ; \mathrm{M}=3671.97$, monoclinic, space group: $P 2_{1} / c$ (\#14), $a=13.4248(13) \AA, b=24.909(2) \AA, c=22.767(3) \AA, \beta=106.708(6)^{\circ}, V=$ $7291.7(12) \AA^{3}, Z=4, D_{\mathrm{c}}=3.345 \mathrm{~g} / \mathrm{cm}^{3}, \mu(\mathrm{MoK} \alpha)=215.962 \mathrm{~cm}^{-1}, R_{1}=0.0876[I>2 \sigma$ $(I)$ ], $w R_{2}=0.2403$ (for all data). GOF $=1.113$ [68383 total reflections and 16705 unique reflections where $I>2 \sigma(I)]$. CCDC No. 1472525. The molecular structure and unit cell packings of TMA-Ge-Pt (space group $P 2_{1} / c$ ) are shown in Figure S11 and Figure S12. 
Submit or recommend next manuscript to SCIRP and we will provide best service for you:

Accepting pre-submission inquiries through Email, Facebook, LinkedIn, Twitter, etc. A wide selection of journals (inclusive of 9 subjects, more than 200 journals)

Providing 24-hour high-quality service

User-friendly online submission system

Fair and swift peer-review system

Efficient typesetting and proofreading procedure

Display of the result of downloads and visits, as well as the number of cited articles

Maximum dissemination of your research work

Submit your manuscript at: http://papersubmission.scirp.org/

Or contact mrc@scirp.org 